\title{
Mapping of groundwater spring potential zone using geospatial techniques in the Central Nepal Himalayas: A case example of Melamchi-Larke area
}

\author{
Motilal Ghimire* (i), Prem Sagar Chapagain and Shova Shrestha \\ Central Department of Geography, Tribhuvan University, Kirtipur, Kathmandu, Nepal. \\ *Corresponding author.e-mail: motighimire@gmail.com
}

MS received 12 June 2017; revised 22 January 2018; accepted 26 April 2018;

published online 19 January 2019

Studies assessing the groundwater spring potential in the Himalayan mountain slopes are very important for sustainable water resources management and build climate resilience in mountains, but such studies are few in the Himalayas. Hence, this paper attempts to identify the groundwater spring potential zone in the Central Himalayas of Nepal. About 412 groundwater springs were surveyed, which were mainly originated from the weathered, jointed or fractured rock aquifers in the high-grade metamorphosed rocks. Eleven influencing factors, viz., altitude, slope gradient, slope shape, relative relief, flow accumulation, drainage density, geology, lineament density, land use and vegetation density were considered in assessing the groundwater spring potential using the weight of evidence method. Weight indicating the probability of groundwater spring occurrence on multiple classes of each factor was calculated and finally summed up to determine the groundwater spring potential. Gentle slope, low relative relief, high flow accumulation, north- and east-facing slopes, denser lineament density, altitude class of 1500-2500 m, high vegetation density, and forest demonstrated a higher likelihood of spring occurrence. Validation of the groundwater spring potential map was successful, which implies the method can be replicated in a similar biophysical environment, where the hydrogeological or geophysical surveyed data is not available.

Keywords. Groundwater spring; weight of evidence; hydrogeology; Himalayas.

\section{Introduction}

Groundwater spring has been used by mountain people since time immemorial to meet the basic needs of the households, livestock and irrigation. These natural springs represent the groundwater storage within the catchments, which form an important component of the Himalayan water budget (Andermann et al. 2012). It is estimated that the flow of water through the fractured basement in the Himalayas is as approximately six times the annual contribution of glacier and snowmelt, which is in contrary to the contemporary notion that held rain, ice and snow as major contributors for the discharge of the large rivers in the Himalayas (Bookhagen and Burbank 2010; Immerzeel et al. 2010).

Like many principal aquifers around the world (Alley et al. 2002; Brekke 2009; Gurdak et al. 2009), the groundwater resources in the aquifers of mountain watersheds of the Himalaya are under the risk of depletion due to human and climatic stress (Valdiya and Bartarya 1989; Tambe et al. 2012; Mukherjee et al. 2015; Chinnasamy and Prathapar 2016). Degradation of the catchments, land use change and extensions of development infrastructures have disrupted the hillslope hydrology largely in the Middle Mountains of 
Nepal. This has led to drying up of spring or reduction of flow regime during the dry months (Gurung and Nepal 2007; Peking University TU 2013; ICIMOD 2015; Chinnasamy and Prathapar 2016; Chapagain et al. 2017). Climate change and variability are emerging as a new threat to ground spring water depletion (Bates et al. 2008; Green 2016). Similarly, recent 2015 earthquake in the Central Nepal Himalayas is reported to have seriously disrupted local water budget as evidenced by drying up of over 5000 groundwater springs (https://globalpressjournal.com/asia /nepal/water-sources-run-dry-nepal-2015-earthqua ke-forcing-people-leave-ancestral-villages-hike-fara way-wells/). Scientific studies indicate that the earthquake-induced crustal deformation and ground shaking alter stream flow and water levels in the wells through consolidation of surficial deposits, fracturing of solid rocks, aquifer deformation and the clearing of fracture-filling materials (Montgomery and Manga 2003; Galassi et al. 2014).

Notwithstanding the above facts, groundwater spring in the Himalayas is poorly understood and insufficiently mapped, and the potential occurrence of groundwater spring in the Himalayas is little studied (Chinnasamy and Prathapar 2016; Sharma et al. 2016). The occurrence of groundwater at any location on the earth is not accidental, but an effect of the interaction of the climatic, geological, hydrological, physiographical and ecological factors (Andermann et al. 2012; Abuzied and Alrefaee 2017). This interaction in the highly deformed Himalayan terrain (resulting from folding, faulting, and development of joints and fractures), which experiences a high rate of weathering and mass movements, microclimatic and ecological variations and change in the landscape, is yet adequately understood (Bookhagen and Burbank 2010; Immerzeel et al. 2010; Andermann et al. 2012; Mahamuni and Kulkarni 2012). Lack of adequate data on geology and structure, soil, geomorphology and groundwater hydrology makes spatial prediction or mapping groundwater spring potential zones even more difficult. Some earlier studies attempted to predict groundwater potential zones by examining spring sources' associations with chosen in situ biophysical terrain factors (Greenbaum 1992; Mukherjee 1996; Marklund and Wörman 2007; Pradhan 2009; Oh et al. 2011; Moghaddam et al. 2015), which have been derived as direct and proxy indicators from geospatial data sources. In this study, similar attempt is made to identify the groundwater spring potential zones in the Higher Mountain portion of the Himalayas in Nepal. Identification of such potential zones will invite scientific research studies, which aim to understand the groundwater hydrology vis-à-vis the aforementioned factors. Validated groundwater spring potential maps can be used for catchment and springshed management as a component for the water resource conservation and management strategy in the mountains.

\subsection{Study area}

The study area lies in the $50 \mathrm{~km}$ northeast of Kathmandu valley. Geographically, it is located in the High Mountain region with a relief between 900 and $6100 \mathrm{~m}$ resulting in varying temperature and rainfall regimes (figure 1). It comprises the watersheds of the Melamchi in the west, Yangri in the middle and the Larke River in the east. These three watersheds are the part of the Indrawati River Basin. Helambu, Baruwa, Bhotang and Kiwool are the prominent areas of the Melamchi-Larke area. The study area delineated for groundwater spring potential mapping covers $320.3 \mathrm{~km}^{2}$.

\subsection{Geological setting}

The geology of the study area comprises the higher Himalayan crystallines containing predominantly the large masses of augen and banded gneisses, interbedded with schists or/and quartzites. These rocks record the higher grade of metamorphism (DMG 2005; Dhital 2015). Based on the lithologic characteristics, the rocks are classified into the following formations (DMG 2005).

The Shermathang Formation is made up of interbedded feldspathic schist, augen gneiss, quartzite and biotic-feldspathic schists. The Pangang Formation constitutes thick-bedded banded gneiss and fine-grained schist. The Dhadkhola Gneiss represents augen gneiss with thin bands quartzite, schists and migmatitic gneiss. The Gyalthung Quartzite comprises medium- to thickbedded grey to dark garnet-biotic quartzite and fine-grained biotite schist. The Simpani Formation constitutes kyanite-biotite schists, migmatite and biotite-feldspathic schist with bands of quartzite. Notable alluvium deposits comprising river terraces at Mahankal area at the south is observed (DMG 2005). NW dipping thrust runs through Ichok in the south and Narpu in the north in a 


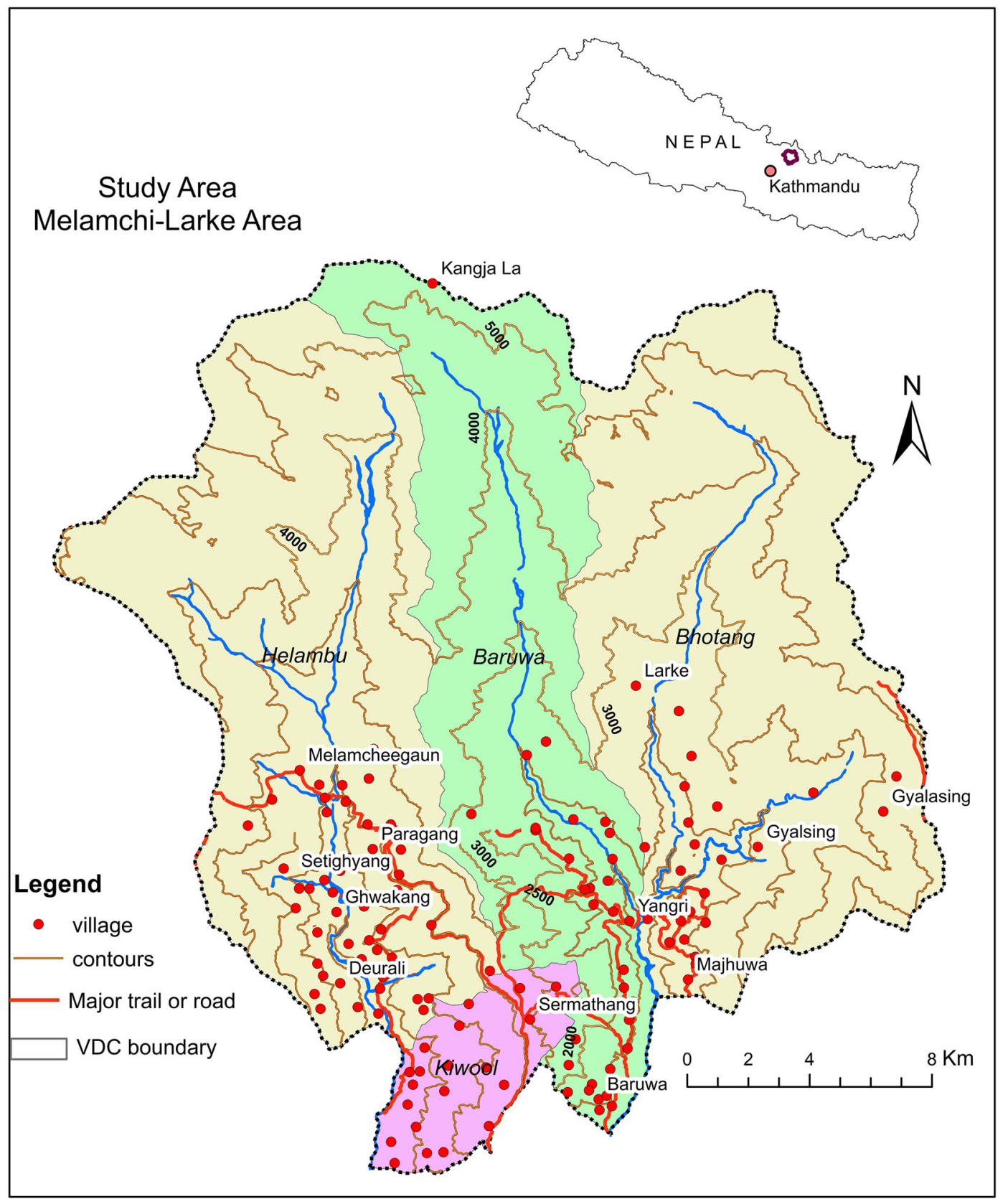

Figure 1. Study area: Melamchi-Larke (part of the Indrawati Basin).

curvilinear pattern, which is offset by the NW-SE fault in the further north and then branches into two SW-NE trending imbricate thrusts (figure 2). The bedrocks are also dipping towards the NW.

Melamchi-Larke area lies north to the Main Central Thrust (MCT), an intracrustal thrust, which separates Lesser Himalayas from the Higher Himalayas. The area adjacent to MCT and other imbricate thrusts is tectonically highly deformed and experiences high accumulation of stress, which is released through a number of tectonic events and structural readjustment producing faults, joints and fractures and foliations. Well-developed two to three sets of joints are seen and numerous randomly oriented and locally controlled joints and fractures owing to crustal deformation are developed on the bedrocks. Various irregularshaped voids and fractures that appear to originate as joints or foliation-parallel partings/openings are also observed (figure 3 ).

These highly sheared and fractured bedrocks are also deeply chemically and biologically weathered on the surface, which is occupied by thick vegetation or cultivation zones on the gentler slopes, 


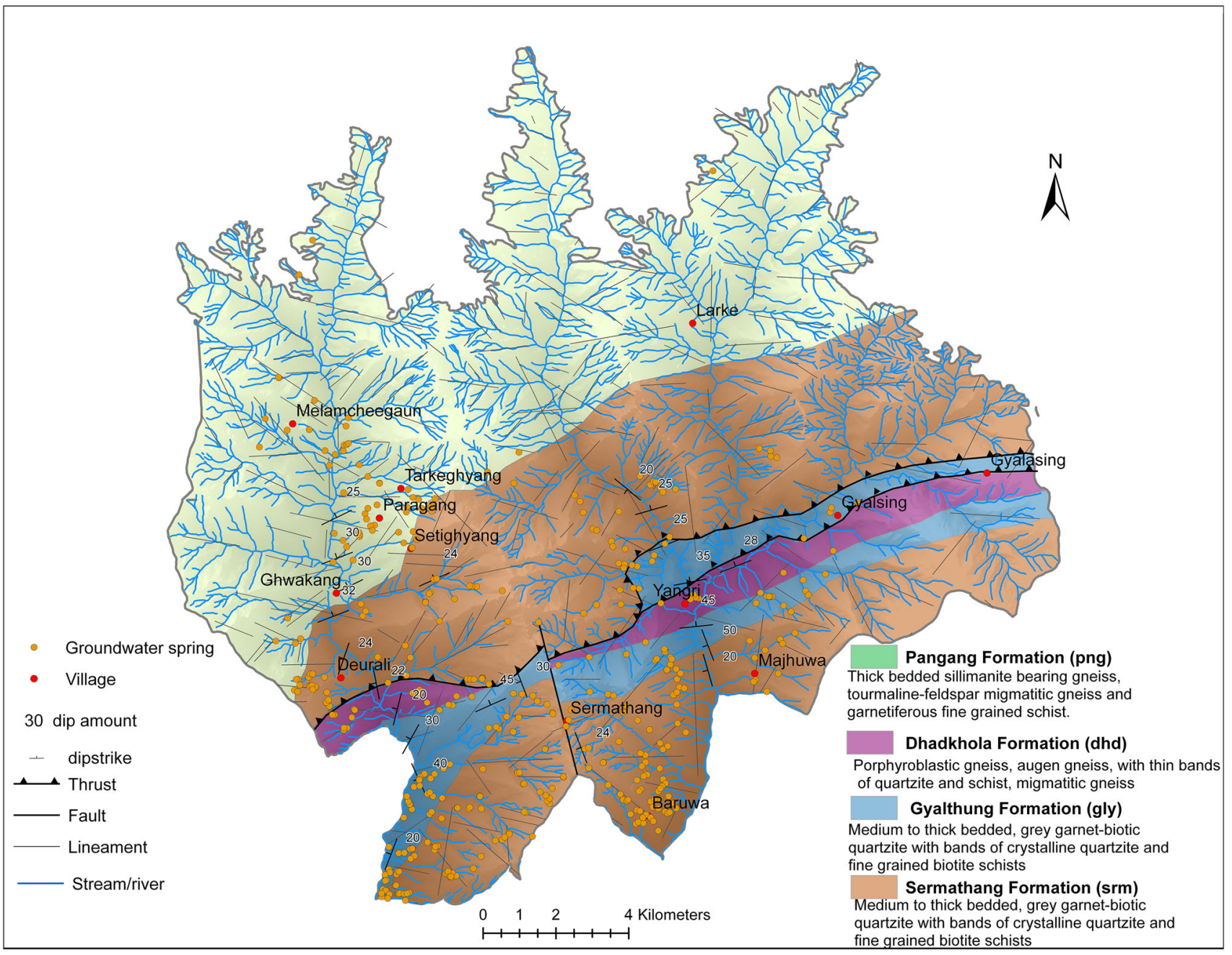

Figure 2. Geological map of the study area.

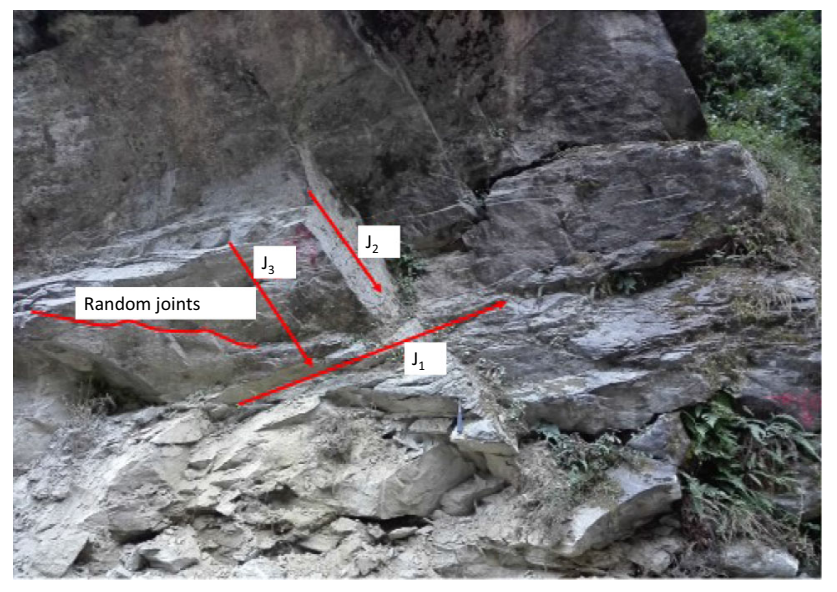

Figure 3. Gneiss exposure in Melamchi area with different joint sets, $J_{1}$ as the foliation plane and $J_{2}$ and $J_{3}$ as other joint sets along with random joints. These joints provide suitable conditions for groundwater flow.

i.e., $\leq 35^{\circ}$. Downslope transport of soil and weathered rocks accumulates as colluvium in the flow convergence zones or colluvial fans in slope breaks or could be transported by streams and river and deposited as alluvial fan or bar deposits in the valleys.

\subsection{Geomorphology}

The study area adjusted to a homoclinal rock structure in which the bedrock typically dips towards the NW at $20-50^{\circ}$ angle. About $60 \%$ of the area lies above the steep slope, i.e., $35^{\circ}, 31 \%$ between $15^{\circ}$ and $35^{\circ}, 5.3 \%$ between $5^{\circ}$ and $15^{\circ}$ slope. The rest of the area is occupied by gentler slope, i.e., $<15^{\circ}$. The relief is very strong, whose amplitude is about $32-35 \%$ at length distances between the valley floor and the ridge in the middle reaches of all three major rivers namely, Melamchi, Yangri and Larke Rivers. Snow-covered area and bare rock, mid-upper slopes and ridges, steep narrow in-valleys, and the river valleys with relatively wide terraces are the major physiographic regions. The major north-south trending ridges, which 
divide the waters of the three principal rivers, and the subparallel ridges demarcating divides of major tributaries developed on major joints are the striking physiographic characteristics.

\subsection{Climate and hydrology}

The climate varies from subtropical to arctic type, within $40 \mathrm{~km}$ south-north range, which has led to variation in biophysical characteristics. The average temperature ranges from $25^{\circ}$ to $11^{\circ} \mathrm{C}$ from subtropical to alpine location. The observed temperature trend between 1975 and 2010 recorded at Nagarkot meteorological station (SI1043) (on the watershed divide of the Melamchi River in SW at $1905 \mathrm{~m}$ asl) showed that the daily maximum temperature increased by $0.01^{\circ} \mathrm{C} / \mathrm{yr}$ and the daily minimum temperature by $0.05^{\circ} \mathrm{C} / \mathrm{yr}$. Increase in average duration of warm spells over the observed period was $+0.02 \mathrm{~d} / \mathrm{yr}$ (Pradhan et al. 2015).

The average yearly precipitation in the study area ranges from above $3000 \mathrm{~mm}$ at higher elevations (Sarmathang, $2600 \mathrm{~m}$ asl) to $1728 \mathrm{~mm}$ at the lowest elevation (Melamchi Bazar, $878 \mathrm{~m}$ asl). More than $85 \%$ of the precipitation is concentrated during the monsoon period, i.e., the middle of May to middle of October. Nearly half the rainfall is received in July and August. The average annual potential evapotranspiration is about $954 \mathrm{~mm}$ (WECS/IMWI 2002). The relative humidity varies from $60 \%$ in the dry season to $90 \%$ in the rainy season, with an average of $75 \%$. Pradhan et al. (2015) observed some long-term trends in the pattern of the rainfall between 1975 and 2010 at Nagarkot, with annual fluctuations. The total annual precipitation on wet days increased by 3.33 $\mathrm{mm} / \mathrm{yr}$, the monthly maximum 1-d precipitation by $0.36 \mathrm{~mm} / \mathrm{yr}$ and the number of consecutive dry days by $0.85 \mathrm{~d} / \mathrm{yr}$. At the Sarmathang station, an increase in monsoon precipitation since 1999 and a decrease in winter precipitation since 2002 were observed with contrasting fluctuations showing an erratic pattern.

The climate change scenario of the Indrawati Basin, which covers the study area, indicates a projected increase of temperature by $+2.0^{\circ} \mathrm{C}$ yearly, $+1.5^{\circ} \mathrm{C}$ in winter and $+2.0^{\circ} \mathrm{C}$ in summer under Representative concentration pathway (RCP) 8.5, respectively, by 2050 (Palazzoli et al. 2015). This projection is in agreement with that of Karmacharya et al. (2007) with little difference. The projection of precipitation has varied with studies (Agrawala et al. 2003; Palazzoli et al.
2015; Pradhan et al. 2015). Of the same basin precipitation in Palazzoli et al. (2015) was projected to decrease by $-46.6 \%$ in winter, $+15 \%$ in summer and $+9.5 \%$ yearly. Comparatively, Agrawala et al. (2003) found $-9.6 \%$ in winter, $-18.1 \%$ in monsoon season and $-13.2 \%$ annually in the Kosi Basin where the Indrawati Basin also lies. Pradhan et al. (2015)'s projection shows $0.9 \%$ increase of precipitation of baseline in the 2020s, $1.4 \%$ in the $2055 \mathrm{~s}$ and $3.0 \%$ in the $2080 \mathrm{~s}$. The study shows a clear increase in rainfall during the early winter months (65-111\% of baseline by the 2050 s) and a small increase in spring and early summer, but a decrease in late winter, mid-to-late summer and autumn.

The daily discharge of the Melamchi River recorded at Helambu River for the period between 1990 and 2007 reveals that almost every year, the predominant frequency of peak discharge is between 30 and $40 \mathrm{~m}^{3} / \mathrm{s}$ (cumecs) until 2005 and the peaks have started to decrease. During 1999 2000 , there was a huge rise in the peak discharge during the monsoon reaching up to 120 cumecs, which was not recorded in the 20-yr period (figure 4). A huge difference in the monsoon and non-monsoon discharge can be observed in the range of $>30$ (monsoon) to $<5$ cumecs (nonmonsoon).

\subsection{Vegetation and land use}

The natural vegetation of the Melamchi Valley ranges from the tropical zone to the alpine pastures towards the north of Jugal Himal. The tropical zone (below $1000 \mathrm{~m}$ ) is represented by Hill Sal Forest. Four forest types, viz., Chir Pine, Broadleaved Forest, Schima-Castonopsis and CastonopsisLaurel. Barren, rocky terrain, snow and glaciers in the alpine parts cover more than $40 \%$ of the study area followed by natural forest $(32 \%)$ and shrubs and bushes (17\%) (figure 2). Agriculture comprises $8 \%$ of the total area, which is largely confined in the southern part, where most of the settlements are located.

\subsection{Population}

The study area has a population of 10,000 with an average household size of 3.9 (CBS 2012). The Tamangs, along with other caste-ethnic groups, are predominant in the lower part of the study area. Hyolmo is the dominant indigenous ethnic group in the upper part of the study area (CBS 2012). The 


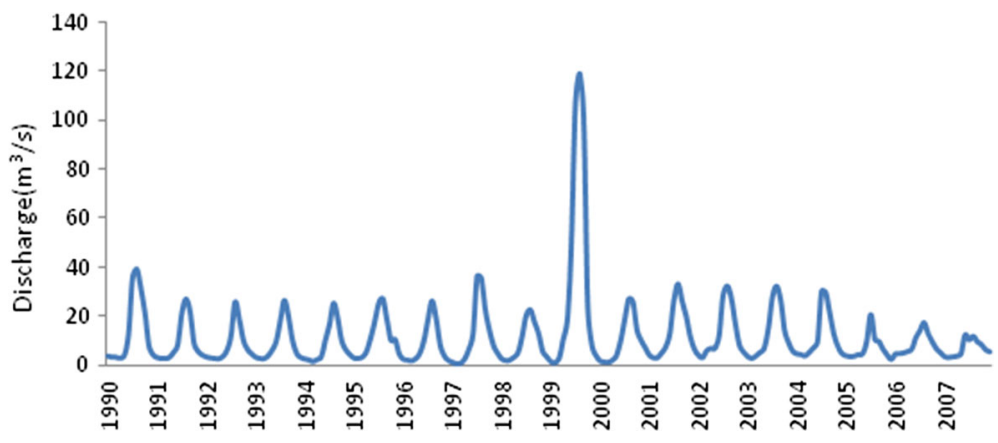

Figure 4. Daily discharge of Melamchi River at Helambu from 1990 to 2007 (source: Department of Hydrology and Meteorology (DHM), Government of Nepal).

major occupation of people living in this region is agriculture, acting as tourist guides, business and migrating to foreign countries as mostly labourers or semi-skilled workers.

\section{Methodology}

\subsection{Past studies}

Assessing groundwater spring potential has been given much emphasis in current times, as water has become a highly prized resource, which needs to be efficiently managed for sustainable use. Planners and engineers have been increasingly using round water potential maps to locate appropriate sites to implement resource explorations (Oh et al. 2011; Guru et al. 2016). Traditionally, the field survey was the method applied to survey the groundwater potential zones (Ganapuram et al. 2009). Mapping of groundwater potential zones using geographical information system (GIS) and remote sensing technology within each geological unit has become a useful procedure in current times. Several pioneering works were done in the mapping of groundwater potential, which used remote sensing (RS) and GIS (NRSA 1987; Salama et al. 1994; Krishnamurthy et al. 1996; Saraf and Choudhury 1998; Sener et al. 2005; Yeh et al. 2009). Using these spatial technologies, factors that governed the groundwater occurrence were mapped and combined to examine the groundwater recharge potential. Recent studies on groundwater potential evaluation (Solomon and Quiel 2006; Jha et al. 2007; Nobre et al. 2007; Tweed et al. 2007; Patil and Mohite 2014; Machiwal and Singh 2015; Moghaddam et al. 2015) have demonstrated the importance of using GIS and remote sensing with various methodological development. Some methods include integration of RS and
GIS and multi-criteria decision-making techniques, eigenvector method (Machiwal and Singh 2015), and bivariate statistical techniques (Oh et al. 2011; Ozdemir 2011; Patil and Mohite 2014; Moghaddam et al. 2015). Yeh et al. (2009) proposed a simple method which considered five major contributing factors: lithology, land cover/land use, lineaments, drainage and slope. The weights of factors contributing to the groundwater recharge are derived using aerial photos, geology maps, a land use database and field verification. Moghaddam et al. (2015) examined the groundwater spring potential map using a bivariate groundwater spring potential map and GIS in a watershed of Iran.

Exploration and identification of groundwater resources in Nepal started as early as 1967 under the government undertaking. Such activities are mainly concentrated in Tarai or Kathmandu valley using field survey (Pandey et al. 2010; http:// www.gwrdb.gov.np/publications.php). Some studies using GIS and RS have assessed the groundwater potential in Kathmandu valley using GIS and RS (Pathak et al. 2009; Pandey et al. 2013). Reviewing the methods from the above studies applied to groundwater potential mapping, the current study will use GIS-based statistical model, i.e., 'Weight of Evidence' by assessing the association of the occurrence of the groundwater springs with in situ parameters that influence groundwater in the High Mountain Region of Central Nepal.

\subsection{Data types and sources}

An inventory of all the springs of the study area was done using GPS during the field survey on site. The survey was conducted below $3000 \mathrm{~m}$ up to the settlement limit of the watershed. Above that elevation, local people have no 
information and the entire area lies within the Langtang National Park, covered by dense forest. Rocky land with the steep slope has no easy access also.

While conducting the GPS survey, the assistance of local persons who knew about the location of springs in each settlement was taken. Expert knowledge and local information included was incorporated in the field survey. A standard checklist was prepared to include the on-site co-occurrence of topography and land use, and water discharge, access and use. Observed spring locations were used for two purposes. Eighty-five per cent of the spring locations were used for preparing a groundwater spring potential map, and the rest $15 \%$ were used for validating the map.

Eleven influencing factors related to spring occurrence and groundwater movement were considered in this investigation. These are slope gradient, slope aspect, altitude, relative relief, slope shape, flow accumulation, drainage density, lithology, lineaments, land use and vegetation density. These factors, which relate to groundwater springs potentials, were identified based on the previous studies, which have used the above factors in potential groundwater recharge mapping (Greenbaum 1992; Krishnamurthy et al. 1996; Mukherjee 1996; Saraf and Choudhury 1998; Shahid et al. 2000; Jaiswal et al. 2003; Sener et al. 2005; Shaban et al. 2006; Pradhan 2009; Oh et al. 2011; Ozdemir 2011; Moghaddam et al. 2015).

The first six parameters were analysed from the digital elevation model (DEM) with $20 \times 20 \mathrm{~m}$ grid size. DEM was created using the elevation contours and spot height layers. The other parameters were obtained from the topographic maps (1:50,000), geological maps and satellite imageries. ArcGIS10.2 was used to extract or calculate the above layers either in vector or raster layers. Recent land use maps were produced by updating the land cover information of topographic maps through visual interpretation of Landsat- 8 multispectral imageries. A $3 \times 3$ low-pass filter was applied to smoothen the imagery for enhancing the interpretation of Landsat-8 acquired in January 2016 (resolution: $30 \mathrm{~m}$ ). Band combinations of 543, 562 and 642 were used for identifying land cover types, i.e., cultivated land, forest, bush, snow, rock and alpine barren. Training sample image pixels representing each cover type were selected from these band combinations for classifying the image. The classification accuracy of $\geq 80 \%$ was accepted. Normalised Difference Vegetation Index map using red and infrared band imageries of Landsat ETM was calculated for preparing vegetation density map (Jensen 2009). Natural linear or gently curvilinear geomorphic features expressing the geological structures such as faults, joints, fractures and lithological contact were extracted from the Landsat imagery by applying gradient filters such as vertical, horizontal and diagonal filters as well as by interpreting individual bands and colour composite images (Sabins 2007; Kolawole et al. 2016).

\subsection{Weight-of-evidence (WoE) for groundwater spring potential mapping}

The mapping of groundwater spring potential zone is based on data-driven method, where the weights of multiple classified layers are assigned by statistical procedures (Van Westen 2002). In this study, WoE, a statistical technique, is used to calculate the probabilistic relationship between the occurrence of spring as the response variable and multiple class terrain factors as predictive variables, which play a role in the occurrence of springs. A flowchart showing the groundwater potential mapping procedure is illustrated in figure 5 .

WoE is the Bayesian approach in a log-linear form (Spiegelhalter 1986), where it estimates the relative importance of the evidence by statistical means. Prior probabilities and posterior probabilities are the important concepts of this approach. Former measures the probability that a terrain factor contains the $S$ (spring) before taking a class of terrain factor $(F)$ into account and its estimation is based on the $S$ density in the study area:

$$
P_{\text {Prior }}=P(S)=\frac{\text { Grids }(\text { Springs })}{\text { Grids }(\text { Total })},
$$

where $P(S)$ is the probability of having a spring, Grid(Springs) is the number of grids with springs on the map and Grid(Total) is the total number of pixels in the map.

Post-probability is then estimated according to the $S$ density for each class of the $F$. It is a modification of earlier estimates of probability, which is expressed as: 


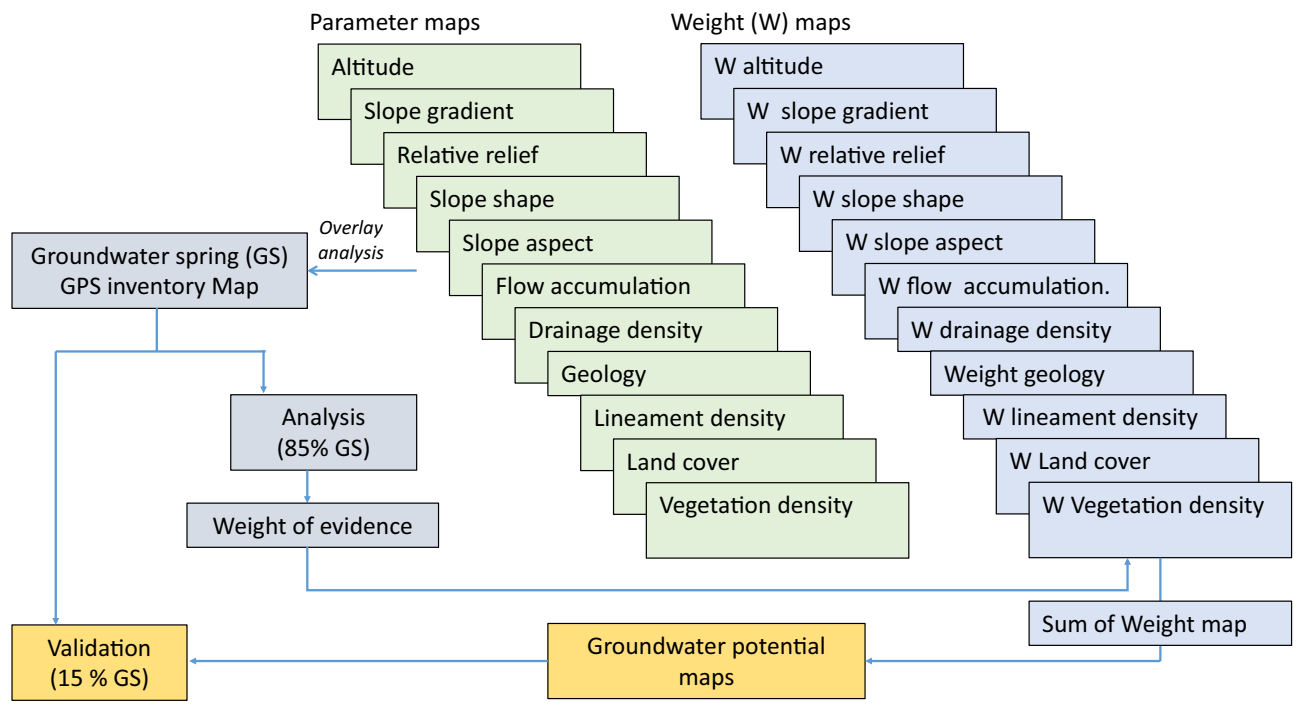

Figure 5. A flowchart showing the groundwater potential mapping procedure.

$$
P(S \mid F)=\frac{P(S \cap F)}{P(F)}=\frac{\operatorname{Grids}(S \cap F)}{\operatorname{Grids}(F)},
$$

where $P(S \mid F)$ is the posterior probability of occurrence of spring in each class of $F$.

Considering this concept, the weight of a class of factor, i.e., multiple class factor map based on the presence or absence of the spring $(S)$ within the area (Bonham-Carter 1994) is calculated in log-linear form:

$$
\begin{aligned}
& W_{i}^{+}=\ln \left(\frac{P\{F \mid S\}}{P\{F \mid \bar{S}\}}\right), \\
& W_{i^{-}}=\ln \left(\frac{P\{\bar{F} \mid S\}}{P\{\bar{F} \mid \bar{S}\}}\right),
\end{aligned}
$$

where $P$ is the probability, $\ln$ is the natural $\log , F$ is the presence of a class of factor, $\bar{F}$ is the absence of a class of factor for spring occurrence, $S$ is the presence and $\bar{S}$ is the absence of the groundwater spring.

$W_{i}^{+}$is used for those grids of a class in a multi-class factor map $(F)$ to indicate the importance of the presence of the factor for the occurrence of springs $(S)$. If $W_{i}^{+}$is positive, the presence of the factor is favourable for the occurrence of springs; and if $W_{i}^{+}$is negative, it is not favourable. Similarly, $W_{i}^{-}$is those for grids of a factor class to indicate the importance of the absence of factors. If $W_{i}^{-}$is positive, the absence of the factor is favourable for the occurrence of springs; and if $W_{i}^{-}$is negative, it is not favourable.
Table 1. Cross-tabulation of groundwater spring and factor maps.

Potential groundwater spring

Groundwater influencing factor

\begin{tabular}{lll}
\cline { 2 - 3 } spring & Present & Absent \\
\hline Present & Ngrid1 & Ngrid2 \\
Absent & Ngrid3 & Ngrid4 \\
\hline
\end{tabular}

The positive and negative weights are calculated using table 1 (modified after Van Westen 2002). The area of interest of the factor maps is divided into grids of $200 \times 200 \mathrm{~m}$, where any spring location would be represented by a grid.

In GIS, the value of $w^{+}$and $w^{-}$can be simply calculated using table 1 as follows:

$$
\begin{aligned}
w^{+}= & \log _{e}[(\operatorname{Ngrid} 1 /(\operatorname{Ngrid} 1+\text { Ngrid} 2)) / \\
& (\text { Ngrid3 } /(\text { Ngrid3 }+ \text { Ngrid } 4))], \\
w^{-}= & \log _{e}[(\text { Ngrid2 } /(\text { Ngrid } 1+\text { Ngrid } 2)) / \\
& (\text { Ngrid4 } /(\text { Ngrid3 }+ \text { Ngrid } 4))] .
\end{aligned}
$$

\subsection{Final weight calculation}

Since all of the maps are multi-class factor maps, containing classes, the presence of one class (e.g., one specific slope aspect unit) implies the absence of the other classes of the same map (e.g., slope aspect map). Therefore, in order to obtain the total weight of each factor, the positive weight of the class is added to the negative weight of the other classes on the same map. This is done by first 


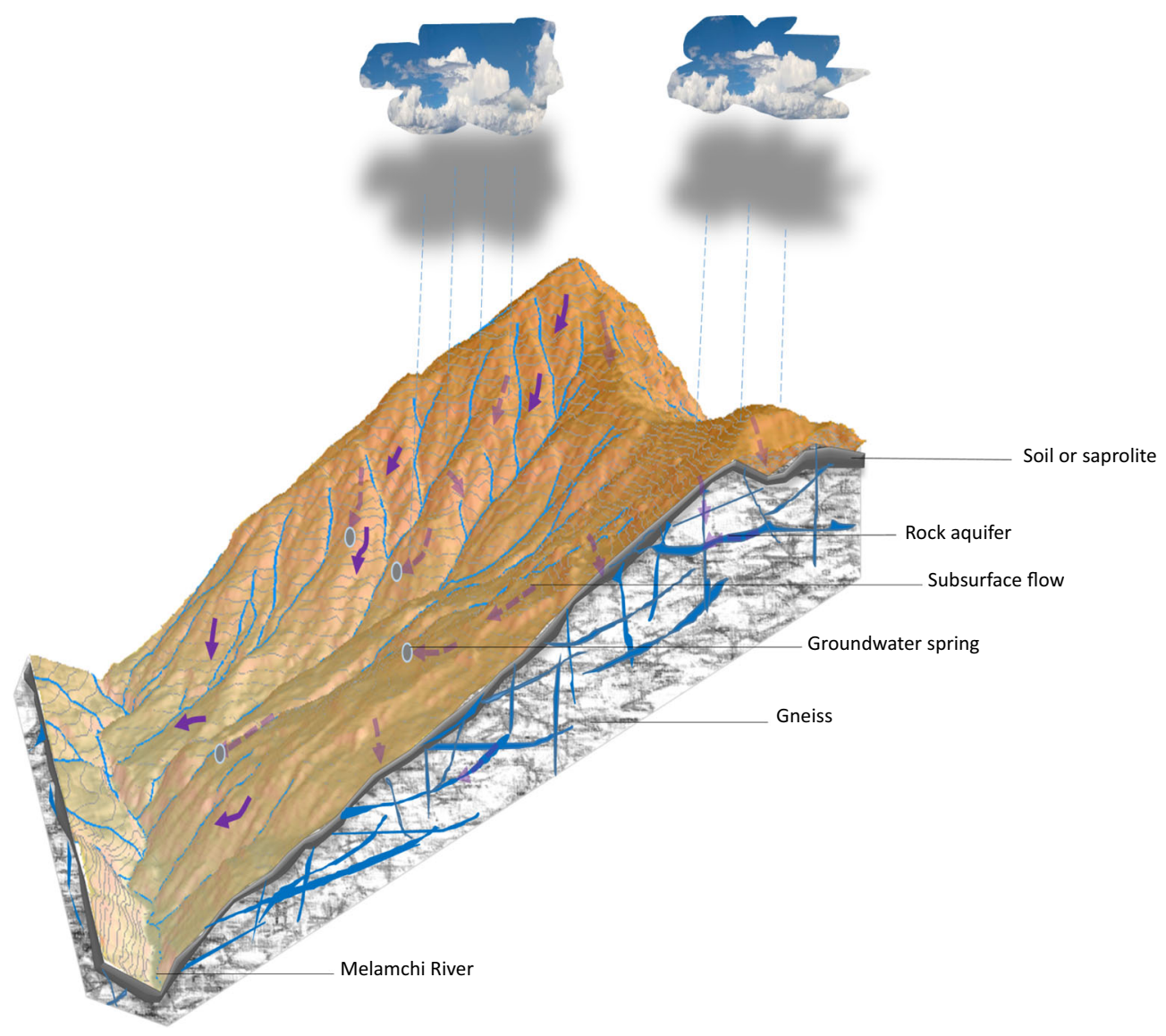

Figure 6. A simple model reflecting the hydrogeology aspect of the groundwater spring of the study area.

adding up all negative weights of the classes of one map and then deducting the negative weight of individual class (Van Westen 2002).

The final weight was then calculated as:

$$
W=W^{+}+\left(\sum W_{i j}^{-}-W_{i}^{-}\right)
$$

in which $\sum W_{i j}^{-}$is the total of all negative weights in a multi-class map.

\section{Results and discussion}

\subsection{Groundwater spring inventory and hydrogeology}

About 412 locations of groundwater springs were mapped in the study area. Out of them, 351 locations of groundwater spring were used for assessing groundwater potential areas and the rest $15 \%$ were randomly selected for validating the result. The source of all the groundwater spring is the rock aquifer, i.e., water stored in rock discontinuities, which include joints or zones of fracture concentration, and openings formed parallel to foliation planes, voids and other weathered openings in the metamorphosed bedrock.

Stated earlier, the rocks underlying the study area are highly metamorphosed, the metamorphism process tends to reduce the porosity of rocks due to high pressure and temperatures. However, tectonic caused intense deformation in the study area has developed faults, deep-seated spaced joints, fractures, voids and cleavage foliations opening, which act as a water conduit and the rock aquifer. Frost action in the higher altitude through the repeated process of freezing and thawing has deepened and widens the rock joints and fractures, which provide porosity for subsurface water flow and storage. Recharge to the rock aquifer system occurs through infiltration of precipitation at the surface. The infiltrating water collects in the soil and weathered rocks, and recharges the underlying bedrock aquifer (figure 6). From the bedrock aquifer, water transmits through the conduits (rock discontinuities) to surface at downslope and emerge through openings or depressions as groundwater springs. Deep soil and weathered rock zone on the slopes below $40^{\circ}$ serve as a groundwater reservoir that feeds the underlying 

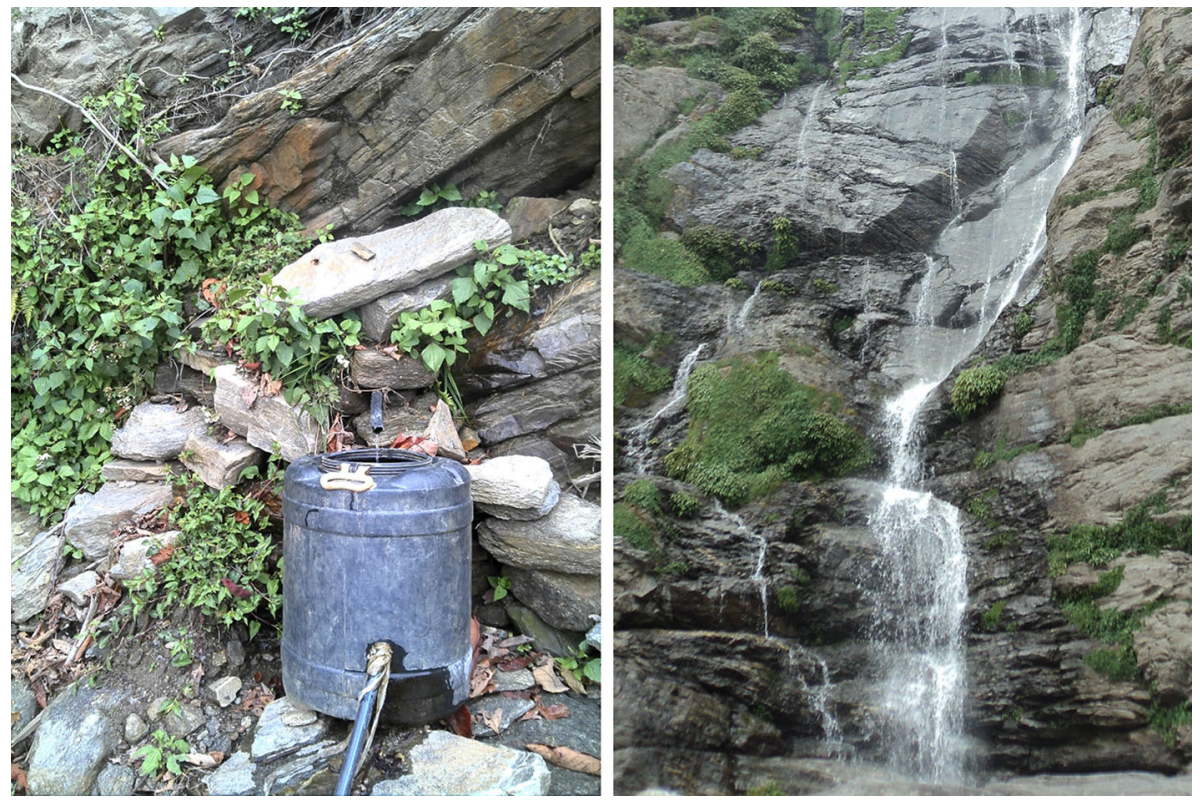

Figure 7. Groundwater spring emerging from the rock joints (left: Baruwa; right: Timbu Jharna, Timbu).

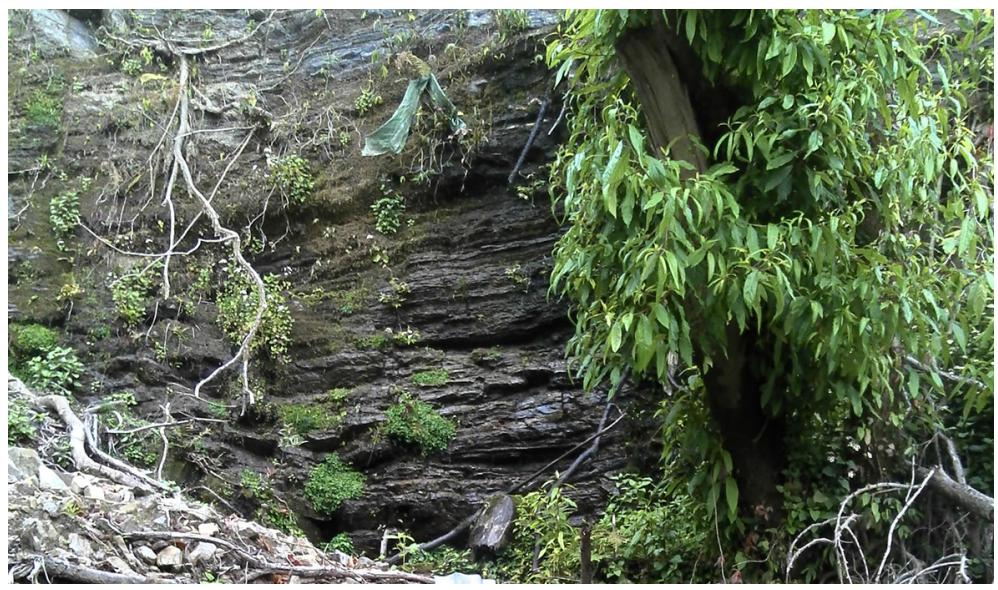

Figure 8. Groundwater spring seeping from the foliation joints of rocks in Baruwa area.

rock discontinuities, which also can store a substantial quantity of water. In the study area, a thick weather zone of $>2 \mathrm{~m}$ was commonly observed; below this zone lies a transitional zone of sapprolite where chemical weathering has changed the chemistry and created open spaces but not yet destroyed the rock's texture. This zone is generally more permeable than the overlying residuum, and in some places is more permeable than the underlying fresh rock and serves to store groundwater and allows it to move into fresh rock.

A simple model reflecting hydrogeology aspect of the groundwater spring has been shown in figure 6 .

About $42 \%$ of groundwater springs are originated from water stored in joints and fractures, foliations of bedrocks. These springs emerged from the exposed bedrock from the outlet provided by their discontinuities. Such joint/fracture springs occur due to the existence of jointed or permeable fracture zones in less permeable high-grade metamorphic rocks (figure 7). Springs emerging from the foliation openings of the exposed bedrocks were also common in the study area (figure 8).

Likewise, rest springs were spotted on soil or colluvium-covered slopes underlain by highly weathered zone (regolith) developed on the bedrock (figure 9). These springs have emerged through the process of discharge of water stored in the colluvium and regolith, as well as transmit of water to surface as a discharge through conduits connected to the rock aquifer (Winter 1998; Crawford and Kath 2005). Many of these springs are depression springs, which are formed when the water table in aquifer reaches the surface 

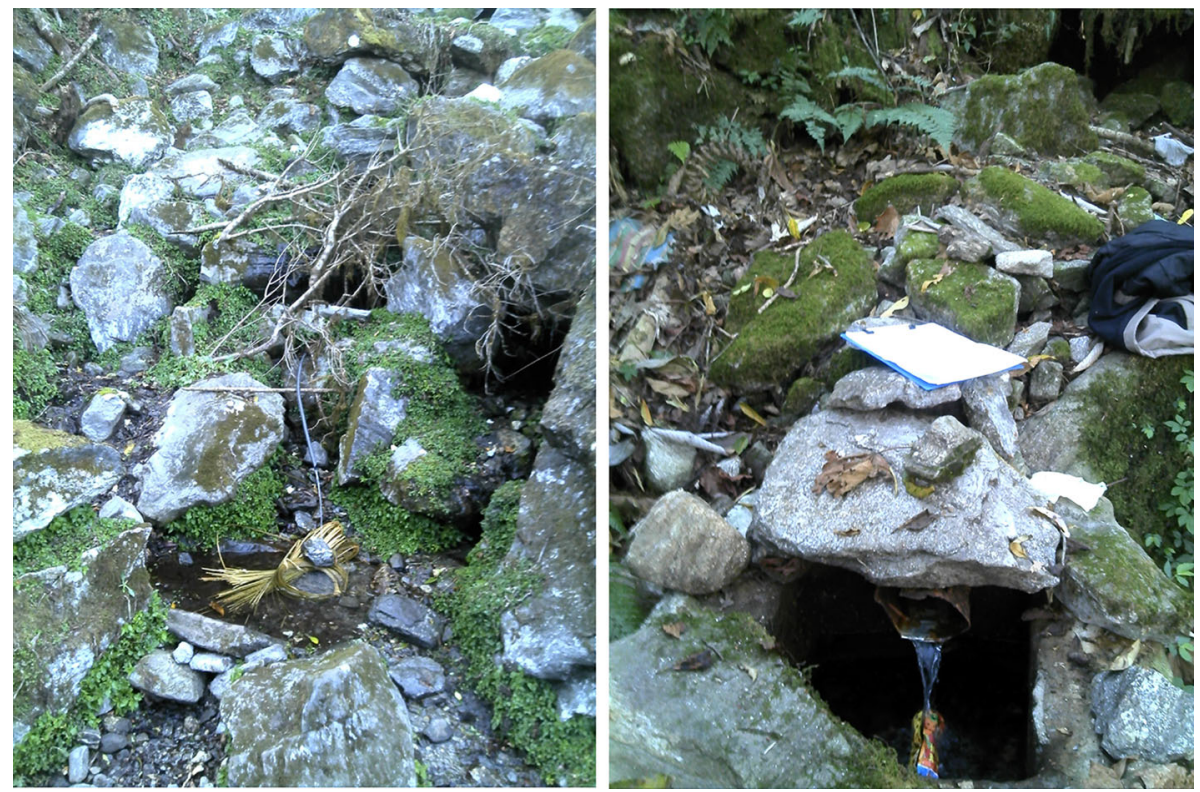

Figure 9. Groundwater spring sprouting from the colluvium and regolith in the depression areas at Timbu of Baruwa (left) and Helambu area (right).
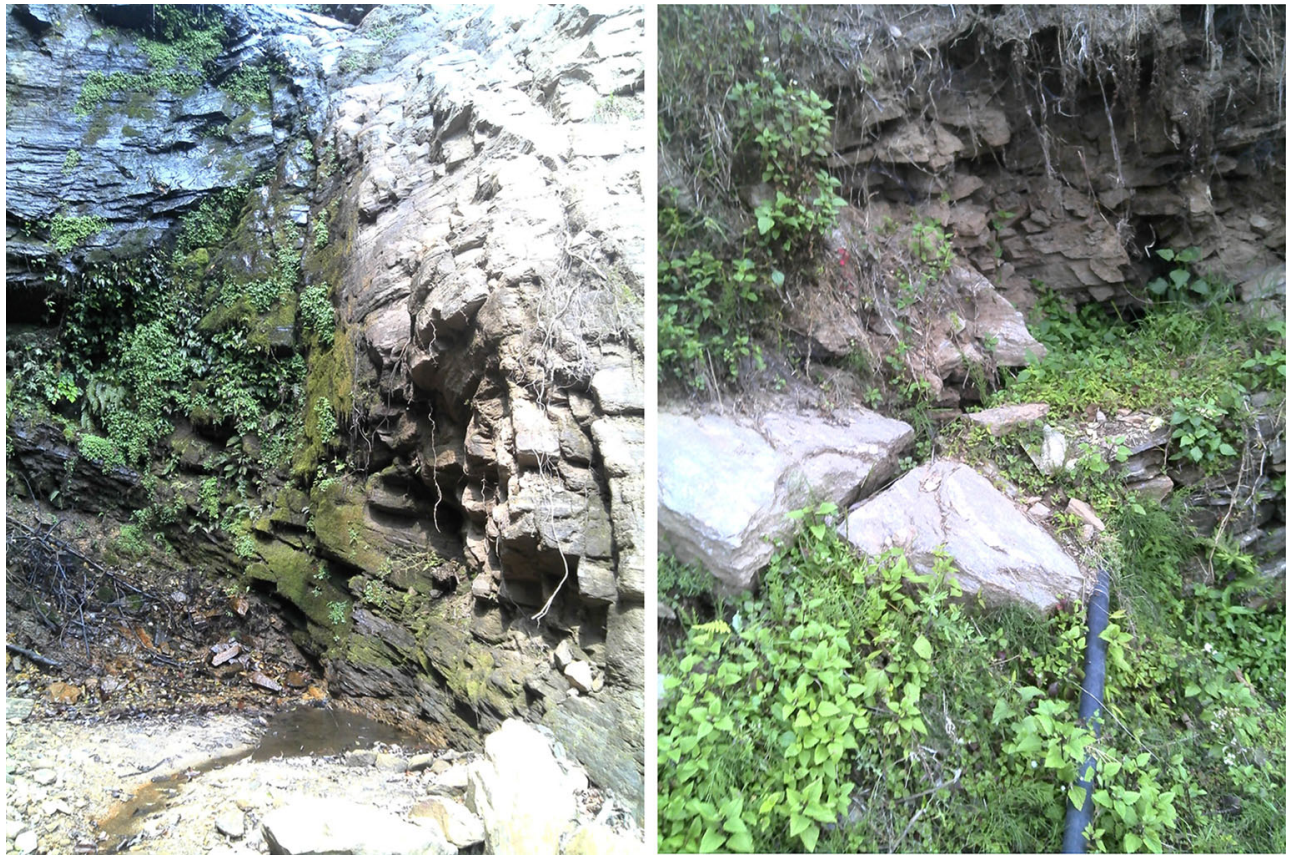

Figure 10. Groundwater spring issuing from the intensely fractured rocks (left) and saprolite containing macropore space in Baruwa Area.

due to topographic undulations (figure 10). Some springs emerging from colluvium or regolith, which lie on less permeable bedrock, are called as contact springs. Many springs have their association with macropores created by tree roots standing or decayed, which allow transmitting subsurface flow downslope. The discharge rate of 321 springs, which were measured, varies from below $5(32.3 \%),>5-50(51.2 \%),>50-500(13.4 \%)$ to above $50(3.1 \%) \mathrm{l} / \mathrm{min}$ (figures 11 and 12 ).

\subsection{Relation between parameters and likelihood} (weight) of the groundwater spring occurrence

\subsubsection{Topography}

Topographic setting signifies the local and regional relief situation and gives an idea about the general direction of groundwater flow and its influence on groundwater recharge and discharge. Slope gradient, slope aspect, slope length, slope shape 


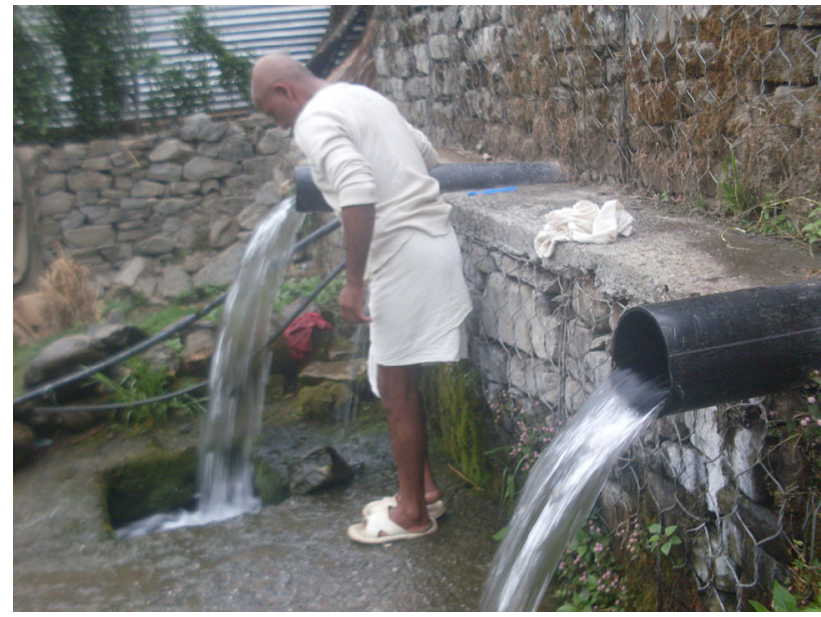

Figure 11. Discharge of a measured spring 'Jor Dhara' at Kiwool.

and relative relief are important topographic parameters that affect the recharge and storage of groundwater. However, the physical properties of rocks and soil control the magnitude of recharge and discharge (Marklund and Wörman 2007). The variability of topographical features such as slope steepness, shape, aspect and relief, slope position is reflected in variable water table configurations, which in turn depends upon the manner in which these features intersect with geological contacts, faults, joints, soil and other deposition characteristics (Higgins et al. 1985; Marklund and Wörman 2007; Younger 2007). The number, per cent and the calculated weight for the topographic parameter class are described in table 2 .

Altitude and relative relief: Water tends to store at lower topography rather than the higher topography. The higher the elevation, the lesser is the groundwater potential and vice versa. Within the settlement limit of the study area, i.e., below snow or glaciers and/or barren rocky zone $(<4000$ $\mathrm{m})$, the likelihood of the ground spring water as indicated by weight seems to decrease with increase in altitude, although the correlation is statistically not significant $(P<0.05)$ (table 1 and figure 13). Generally, the groundwater seepage zone increases as the altitude increases and the areas for gaining rainwater for infiltration progressively decrease with the decline in altitude. The weight of ground spring water was found to be higher in lower relative (or local) relief than the higher

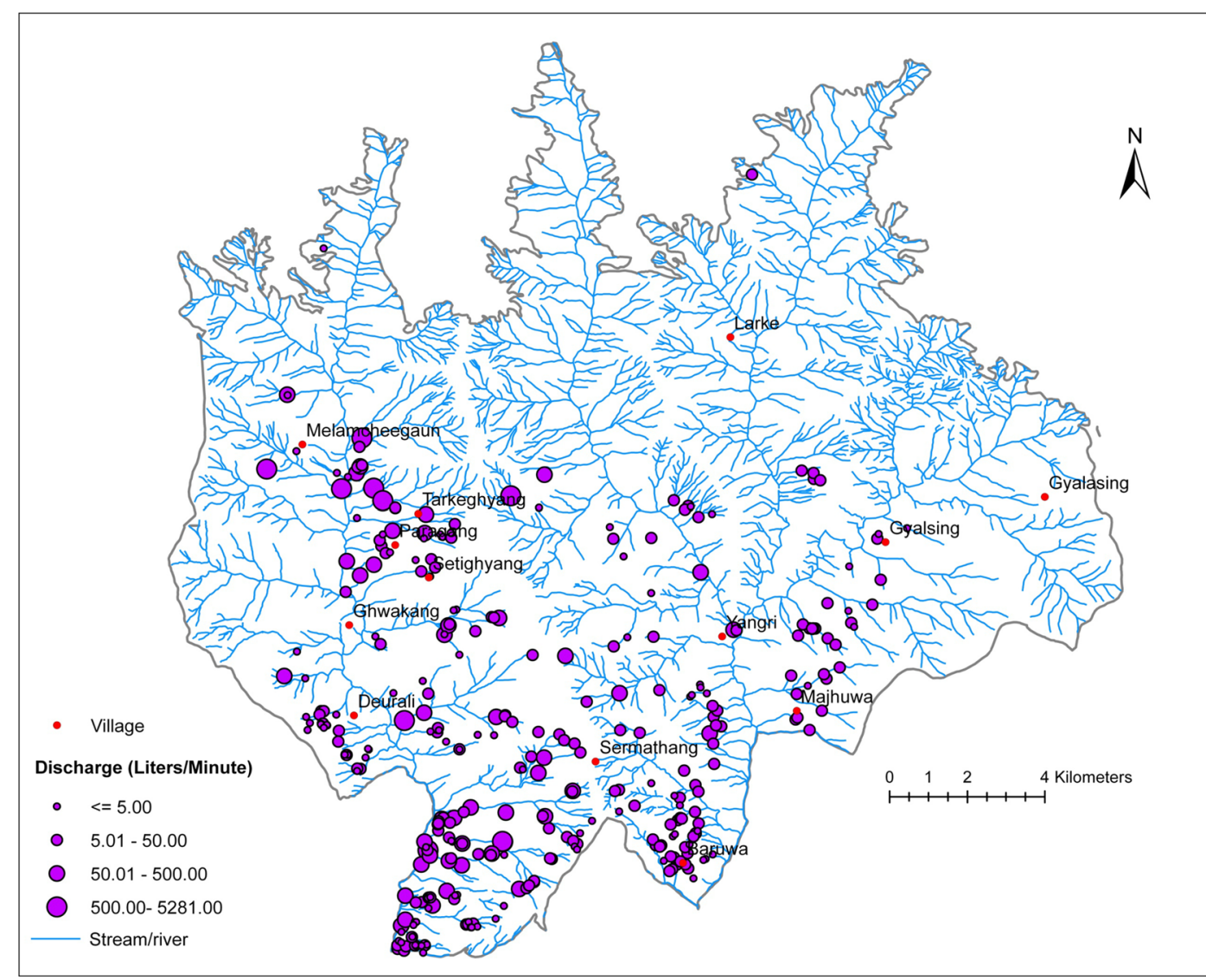

Figure 12. Map showing the discharge rate of measured 321 springs at various locations. 
Table 2. Topography and groundwater springs.

\begin{tabular}{|c|c|c|c|c|c|c|c|}
\hline $\begin{array}{l}\text { Altitude } \\
\text { class (m) }\end{array}$ & $\begin{array}{l}\text { No. of } \\
\text { springs }\end{array}$ & $\begin{array}{l}\text { No. class } \\
\text { grids }\end{array}$ & \% Springs & $\begin{array}{l}\% \text { Class } \\
\text { grids }\end{array}$ & $W_{i}^{+}$ & $W_{i}^{-}$ & $W$ \\
\hline$<1500$ & 48 & 390 & 13.675 & 4.884 & 1.104 & -0.101 & 1.129 \\
\hline $1500-2000$ & 130 & 1254 & 37.037 & 15.702 & 0.911 & -0.301 & 1.136 \\
\hline $2000-2500$ & 136 & 1863 & 38.746 & 23.328 & 0.526 & -0.23 & 0.681 \\
\hline $2500-3000$ & 33 & 1958 & 9.402 & 24.518 & -0.998 & 0.196 & -1.27 \\
\hline $3000-3500$ & 1 & 1786 & 0.285 & 22.364 & -4.419 & 0.267 & -4.762 \\
\hline $3500-4000$ & 3 & 735 & 0.855 & 9.204 & -2.429 & 0.093 & -2.599 \\
\hline Total & 351 & 7986 & 100 & 100 & & -0.076 & \\
\hline \multicolumn{8}{|c|}{ Slope in degrees } \\
\hline$<5$ & 7 & 122 & 1.994 & 1.527 & 0.281 & -0.005 & 0.278 \\
\hline $5-15$ & 17 & 222 & 4.843 & 2.778 & 0.591 & -0.022 & 0.605 \\
\hline $15-25$ & 86 & 1161 & 24.501 & 14.54 & 0.554 & -0.129 & 0.675 \\
\hline $25-35$ & 138 & 2809 & 39.316 & 35.173 & 0.117 & -0.069 & 0.178 \\
\hline $35-45$ & 84 & 2562 & 23.932 & 32.082 & -0.305 & 0.119 & -0.432 \\
\hline$>45$ & 19 & 1110 & 5.413 & 13.901 & -0.971 & 0.099 & -1.078 \\
\hline Total & 351 & 7986 & 100 & 100 & & -0.008 & \\
\hline \multicolumn{8}{|c|}{ Relative relief $\left(\mathrm{m} / 200^{2} \mathrm{~m}\right)$} \\
\hline 50 & 156 & 1913 & 44.321 & 23.953 & 0.655 & -0.324 & 0.958 \\
\hline 75 & 137 & 3486 & 39.058 & 43.655 & -0.116 & 0.082 & -0.219 \\
\hline 100 & 58 & 2587 & 16.62 & 32.392 & -0.689 & 0.22 & -0.931 \\
\hline Total & 351 & 7986 & 100 & 100 & 0 & -0.021 & \\
\hline \multicolumn{8}{|l|}{ Slope shape } \\
\hline Convex & 99 & 2549 & 28.205 & 31.918 & -0.129 & 0.056 & -0.188 \\
\hline Straight & 131 & 2584 & 37.322 & 32.357 & 0.15 & -0.08 & 0.226 \\
\hline Concave & 121 & 2853 & 34.473 & 35.725 & -0.037 & 0.02 & -0.061 \\
\hline Total & 351 & 7986 & 100 & 100 & & -0.004 & \\
\hline \multicolumn{8}{|c|}{ Slope aspect } \\
\hline Flat & 1 & 58 & 0.285 & 0.726 & -0.974 & 0.005 & -0.968 \\
\hline $\mathrm{N}$ & 40 & 562 & 11.396 & 7.032 & 0.5 & -0.049 & 0.56 \\
\hline $\mathrm{NE}$ & 32 & 955 & 9.117 & 11.962 & -0.294 & 0.035 & -0.318 \\
\hline $\mathrm{E}$ & 62 & 1147 & 17.664 & 14.364 & 0.206 & -0.039 & 0.256 \\
\hline SE & 28 & 901 & 7.977 & 11.286 & -0.372 & 0.04 & -0.401 \\
\hline $\mathrm{S}$ & 34 & 999 & 9.687 & 12.513 & -0.278 & 0.035 & -0.302 \\
\hline SW & 54 & 1185 & 15.385 & 14.84 & 0.026 & -0.005 & 0.041 \\
\hline $\mathrm{W}$ & 56 & 1288 & 15.954 & 16.129 & -0.023 & 0.004 & -0.028 \\
\hline NW & 44 & 890 & 12.536 & 11.149 & 0.111 & -0.015 & 0.126 \\
\hline Total & 351 & 7986 & 100 & 100 & & 0.011 & \\
\hline
\end{tabular}

Note: 1 grid $=200 \times 200 \mathrm{~m}$.

relative relief. This relation implies that less rugged topography and low relief allows for more space and time to percolate the rainwater and raise the groundwater to favourably provide the outlet for groundwater discharge. Such areas represent the subdued part of the topography where slopes are relatively gentle, as well as downslope, where the rock and colluvium aquifer reach the surface and seep out as spring. High internal relief indicates highly rugged and dissected topography made of runoff, erosion and incisions, which generally favours taping and draining rainwater through gullies and stream developed on the steeper slopes. High mountainous relief also promotes deep circulation of groundwater, denying access to groundwater outcrops (Forster and Smith 1988).

Slope gradient: Slope gradient regulates the amount and rate of runoff and water percolation into the subsurface and accumulates as groundwater storage. In the study area, the slope gradient indicates an inverse relation with the occurrence of groundwater spring. The likelihood of occurrence (weight) of the groundwater spring increases 


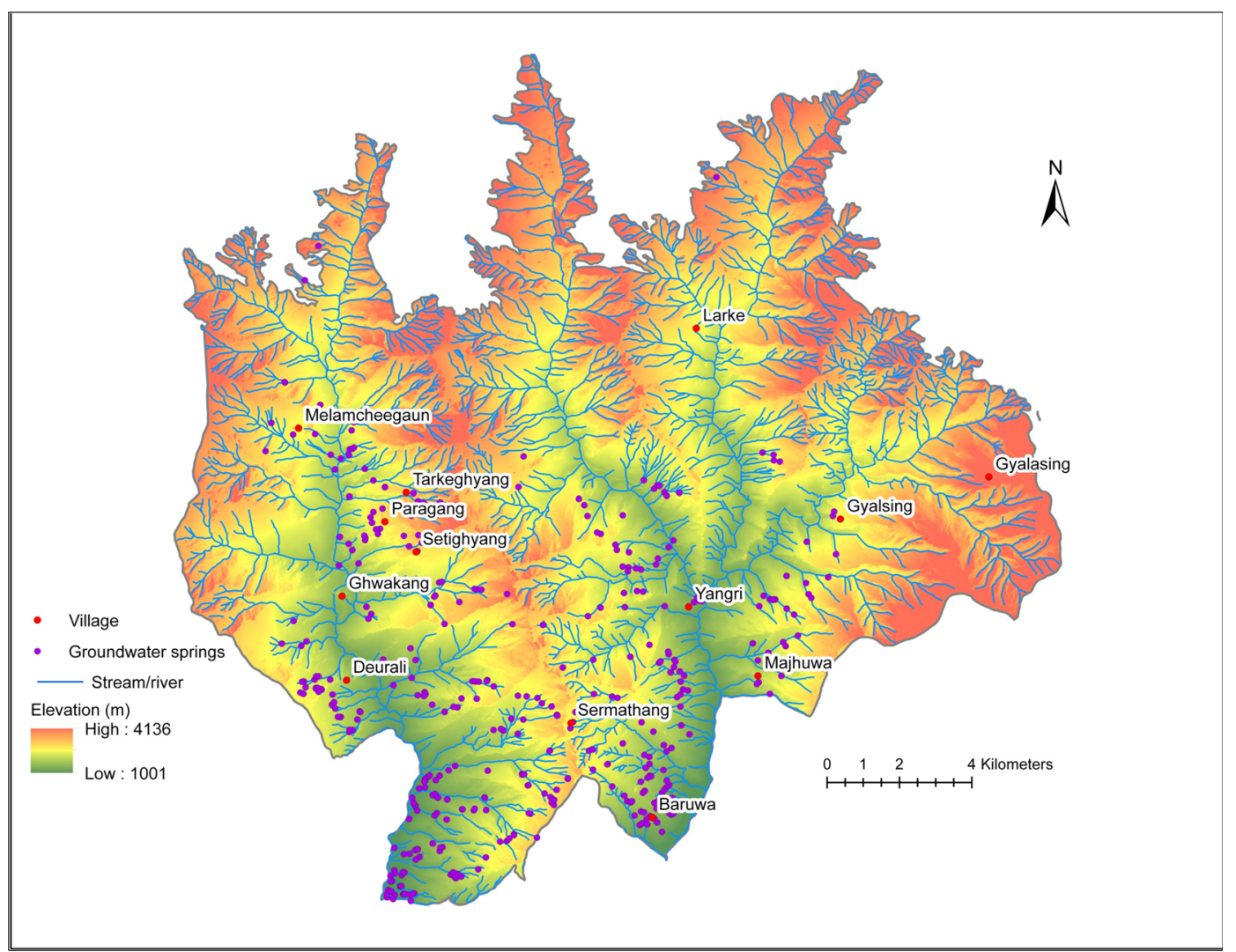

Figure 13. Altitude map (digital elevation model) of the study area.

with decrease of slope gradient (figure 14) and the correlation is significant, i.e., $r^{2}=0.68(P<$ $0.10, n=6)$. In general, the hydrogeologic landscapes with relatively steep terrain would not be expected to have an appreciable amount of groundwater recharge compared to runoff (e.g., Hudson and Anderson 2006). On very gentle slopes $\left(<5^{\circ}\right)$, the surface runoff is slow, allowing more time for rainwater to percolate and is considered as good groundwater potential zone, whereas steeper slopes facilitate high runoff, allowing less residence time for rainwater hence comparatively less infiltration and poor groundwater potential (Florinsky 2000; Rao 2006).

Slope shape: Geomorphic significance of the shape of the slopes can be explained by its role in accumulating or dispersing the runoff. The concave slopes allow for the accumulation of runoff and deposition of colluvium, which strongly favours recharge as well as seepage as springs from hillslopes (Younger 2007; Ghimire 2011). Whereas convex slopes, which are generally the upper segments of the slopes closer to the ridgeline, are runoff dispersal slopes that discourage the recharge of groundwater. The straight slopes in the study area are generally steep footslope components produced by bedrock incision by fluvial processes induced by active tectonics (Lavé and Avouac 2001). The weight indicating the groundwater spring potential was found to be high on straight and concave slopes. The high frequency of the springs on straight slopes indicates the seepage of groundwater flow on a larger quantity from the downslope below the concave slopes, which acts as an intake of rainwater for groundwater recharge.

Slope aspect: Slope aspect reflects the moisture retention, vegetation and its relation to rain-bearing wind and attitude of rock bedding, which in turn influences the physical properties of slope material and soils and thereby the potential for groundwater. In the study area, the north, northeast and east facing slopes have the positive weight for groundwater potential (figure 15). The role of bedding structure and geology in relation to an aspect, and the slope aspect's role in moisture regime seem to have played a role in determining the groundwater spring potential. Although the south facing slopes in Nepal Himalayas receive more rainfall, they are steep due to geological 


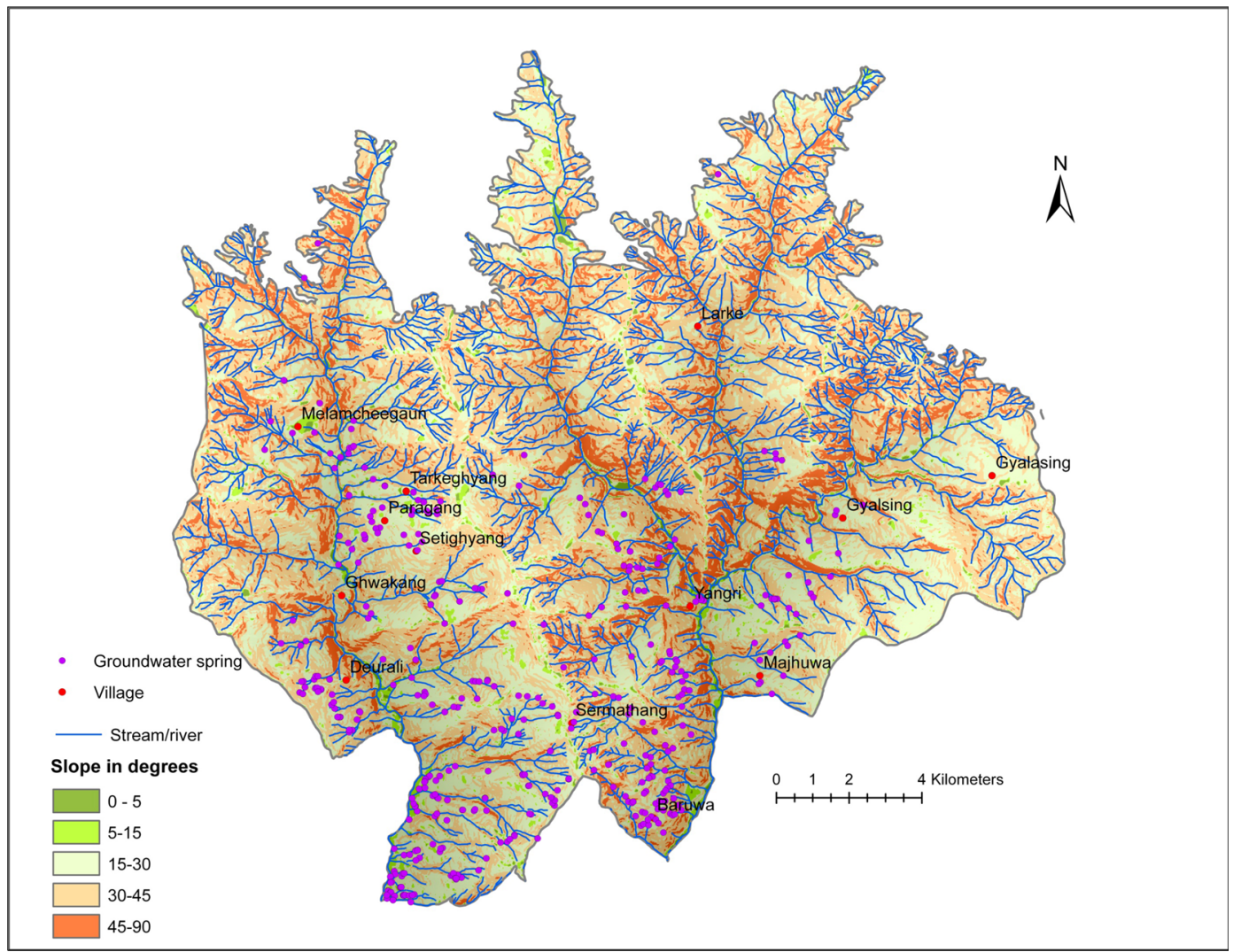

Figure 14. Slope gradient map of the study area.

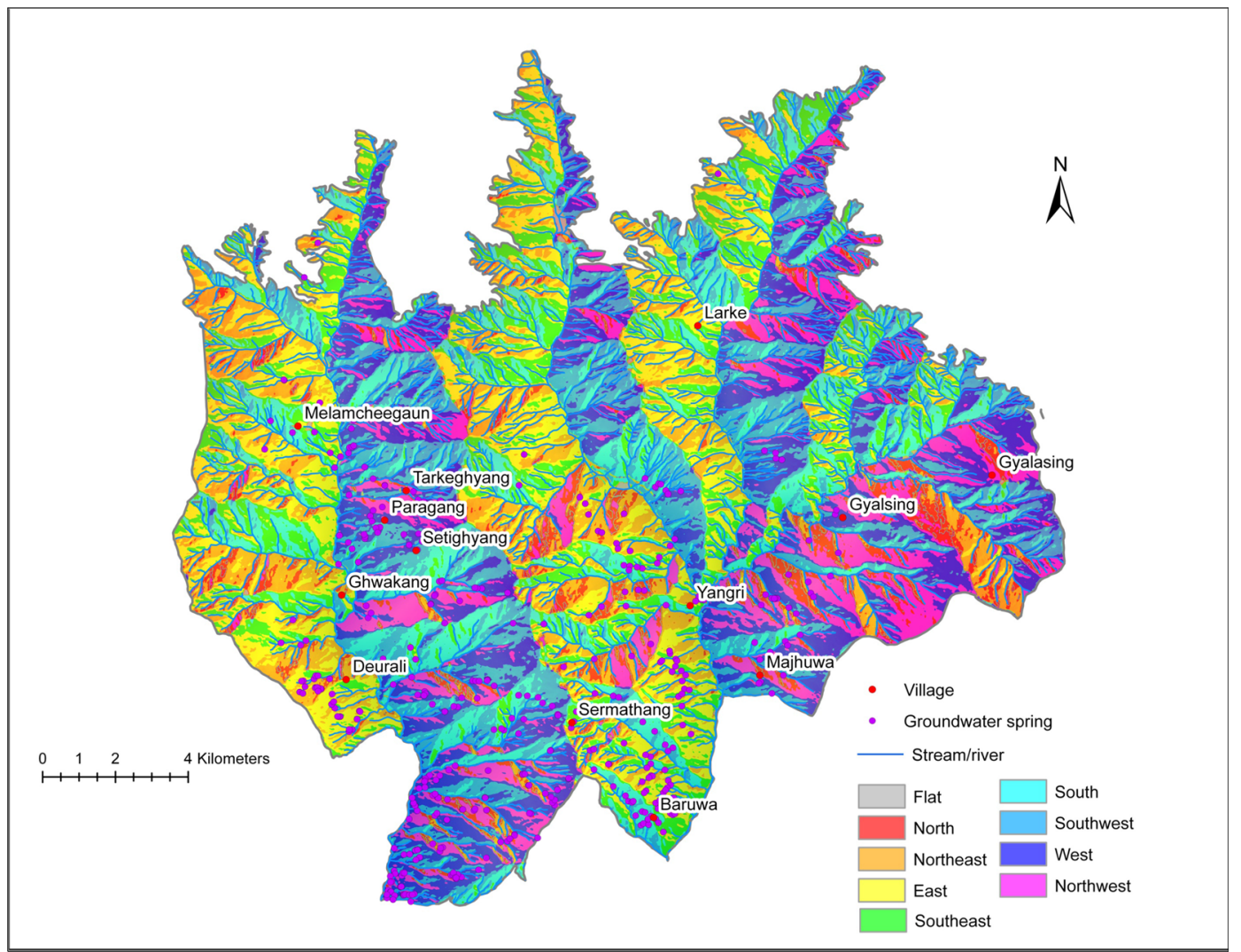

Figure 15. Slope aspect map of the study area. 
Table 3. Drainage, flow accumulation zone and groundwater spring.

\begin{tabular}{|c|c|c|c|c|c|c|c|}
\hline Class & $\begin{array}{l}\text { No. of } \\
\text { springs }\end{array}$ & $\begin{array}{l}\text { No. class } \\
\text { grids }\end{array}$ & $\%$ Springs & $\begin{array}{c}\% \text { Class } \\
\text { grids }\end{array}$ & $W_{i}^{+}$ & $W_{i}^{-}$ & $W$ \\
\hline \multicolumn{8}{|c|}{ Drainage density $\left(\mathrm{km} / \mathrm{km}^{2}\right)$} \\
\hline$<1.5$ & 21 & 523 & 5.983 & 6.551 & -2.127 & 0.636 & 0.059 \\
\hline $2-2.5$ & 145 & 1752 & 41.311 & 21.940 & -0.415 & 0.449 & 1.958 \\
\hline $3-3.5$ & 146 & 2768 & 41.595 & 34.667 & -0.458 & 0.535 & 1.829 \\
\hline $3.5-4$ & 33 & 2245 & 9.402 & 28.116 & -1.840 & 0.797 & 0.185 \\
\hline $4<$ & 6 & 697 & 1.709 & 8.726 & -3.003 & 0.405 & -0.587 \\
\hline Total & 351 & 7986 & 100 & 100 & & 2.822 & \\
\hline \multicolumn{8}{|c|}{ Flow accumulation (no. of grids) } \\
\hline$>100$ & 181 & 3580 & 51.57 & 44.795 & 0.148 & -0.136 & 0.233 \\
\hline 100 & 91 & 2132 & 25.93 & 26.677 & -0.030 & 0.011 & -0.092 \\
\hline 50 & 51 & 1565 & 14.53 & 19.582 & -0.310 & 0.064 & -0.425 \\
\hline 10 & 8 & 232 & 2.28 & 2.903 & -0.252 & 0.007 & -0.310 \\
\hline$<10$ & 20 & 483 & 5.70 & 6.044 & -0.061 & 0.004 & -0.117 \\
\hline Total & 351 & 7992 & 100 & 100 & & -0.051 & \\
\hline
\end{tabular}

Table 4. Geology and groundwater spring.

\begin{tabular}{lccccrrr}
\hline Unit & $\begin{array}{c}\text { No. of } \\
\text { springs }\end{array}$ & $\begin{array}{c}\text { No. class } \\
\text { grids }\end{array}$ & $\begin{array}{c}\text { \% Springs } \\
\text { area }\end{array}$ & $W_{i}^{+}$ & $W_{i}^{-}$ & $W$ \\
\hline Geological units & & & & & & & \\
Pangang Formation & 60 & 3516 & 17.094 & 44.032 & -0.974 & 0.415 & -1.412 \\
Gyalthung Formation & 68 & 709 & 19.373 & 8.884 & 0.835 & -0.128 & 0.940 \\
Shermathang Formation & 196 & 3377 & 55.840 & 42.292 & 0.293 & -0.278 & 0.548 \\
Dhadkhola Formation & 27 & 383 & 7.692 & 4.792 & 0.501 & -0.032 & 0.511 \\
Total & 351 & 7986 & 100 & 100 & & -0.023 & \\
Lineament density $\left(\mathrm{km} / \mathrm{km}^{2}\right)$ & & & & & & & \\
0-0.72 & 41 & 1530 & 11.7 & 19.2 & -0.512 & 0.093 & -0.629 \\
0.73-0.95 & 45 & 1618 & 12.8 & 20.3 & -0.474 & 0.094 & -0.591 \\
0.96-1.18 & 62 & 1642 & 17.7 & 20.6 & -0.158 & 0.038 & -0.219 \\
1.18-1.50 & 1647 & 26.8 & 20.6 & 0.275 & -0.084 & 0.336 \\
$1.50-3.68$ & 109 & 1549 & 31.1 & 19.4 & 0.499 & -0.163 & 0.638 \\
Total & 351 & 7986 & 100 & 100 & & -0.023 & \\
\hline
\end{tabular}

reasons with thin soil cover to promote higher runoff as well as because of high solar radiation, water in soil dries out faster than the north facing slopes. Hence, the south facing ridge slopes are usually dry and have low groundwater potential (Paudel and Vetaas 2014). It is acknowledged that in opposing slope aspects, the difference in soil, vegetation, water retention and infiltration rates is observed (Higgins et al. 1985; Younger 2007).

\subsubsection{Drainage density and flow accumulation}

Drainage density points to rock permeability and infiltration capacity and therefore recharge capacity. It indicates the rate that precipitation infiltrated compared to surface runoff where rocks are highly permeable, infiltration to groundwater is high and less water is transported in rivers as surface water and vice versa. Low drainage density is, therefore, related to higher recharge and higher groundwater potential (Murthy 2000; Thangarajan 2007; Magesh et al. 2012). However, our study does not reveal such relation. No definite association between the occurrence of groundwater spring and drainage density is observed (table 3). Because all the geological units of the area are made of high-grade metamorphic rocks whose permeability does not vary significantly; therefore, the drainage density seems to be controlled by localised factors. Groundwater recharge and discharge are mostly through rock discontinuities. Many of drainage lines are controlled by joints and faults. 


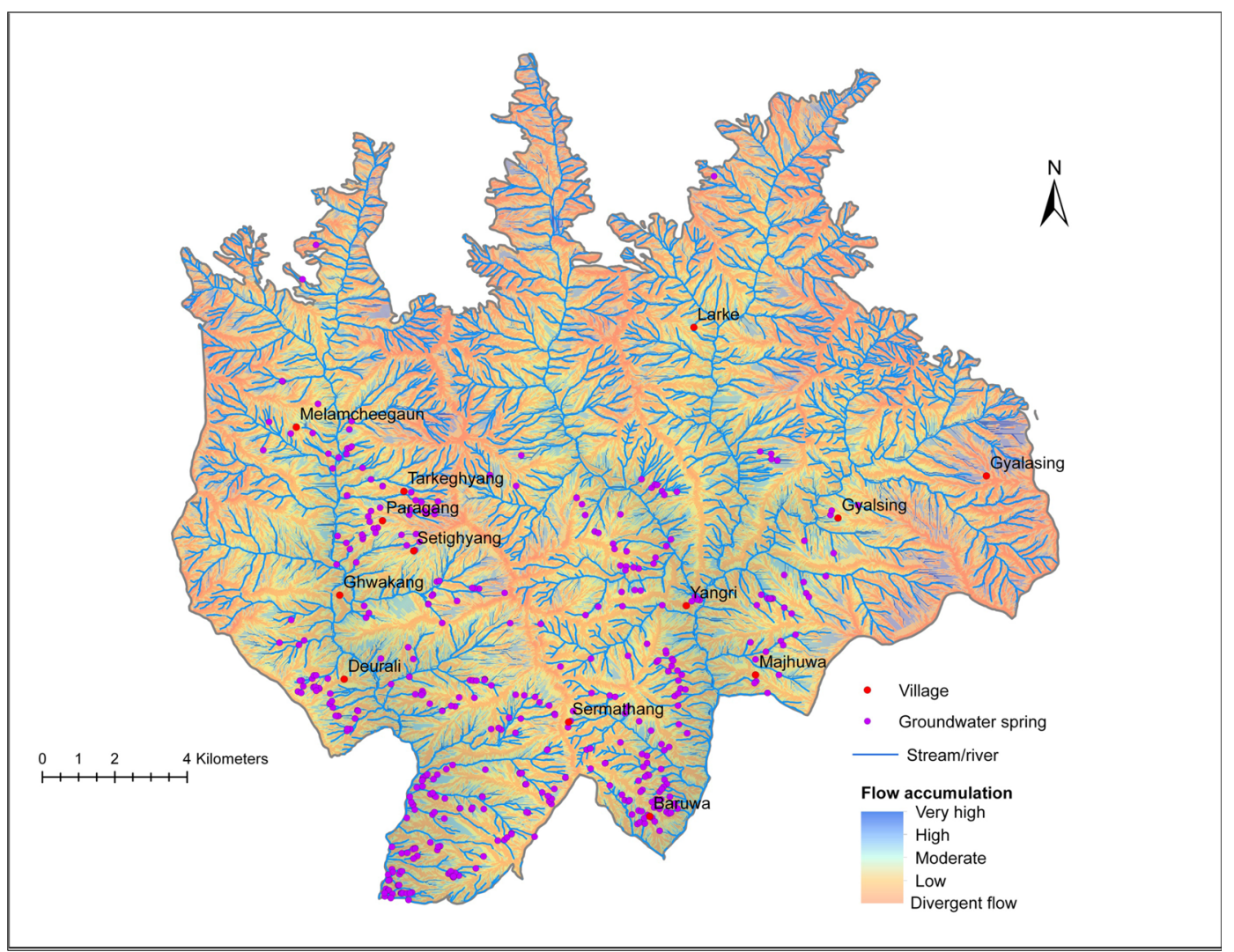

Figure 16. Flow accumulation map of the study area.

Table 5. Land use and vegetation index, and ground spring water.

\begin{tabular}{|c|c|c|c|c|c|c|c|}
\hline Class & $\begin{array}{l}\text { No. of } \\
\text { springs }\end{array}$ & $\begin{array}{l}\text { No. class } \\
\text { grids }\end{array}$ & $\% \mathrm{LS}$ & $\begin{array}{c}\% \text { Class } \\
\text { area }\end{array}$ & $W_{i}^{+}$ & $W_{i}^{-}$ & $W$ \\
\hline \multicolumn{8}{|l|}{ Land use } \\
\hline Barren & 3 & 147 & 0.85 & 1.84 & -0.790 & 0.010 & -0.823 \\
\hline Forest & 189 & 1086 & 53.85 & 13.60 & 1.523 & -0.648 & 2.149 \\
\hline Cultivation & 33 & 4204 & 9.402 & 52.64 & -1.76 & 0.692 & -2.473 \\
\hline Cut and cliff & 0 & 158 & 0.000 & 1.98 & -11.51 & 0.021 & -11.55 \\
\hline Grass & 126 & 2314 & 35.90 & 28.97 & 0.225 & -0.107 & 0.310 \\
\hline Others & 0 & 78 & 0.000 & 0.976 & -11.513 & 0.010 & -11.54 \\
\hline Total & 351 & 7986 & 100.00 & 100.00 & & -0.022 & \\
\hline \multicolumn{8}{|c|}{ Normalised difference vegetation index } \\
\hline$<0$ & 2 & 245 & 0.489 & 3.069 & -1.875 & 0.027 & -1.983 \\
\hline $0-0.2$ & 6 & 1010 & 1.711 & 12.641 & -2.039 & 0.124 & -2.243 \\
\hline $0.2-0.4$ & 82 & 2040 & 23.472 & 25.545 & -0.088 & 0.029 & -0.198 \\
\hline $0.4-0.5$ & 159 & 2398 & 45.232 & 30.030 & 0.433 & -0.255 & 0.607 \\
\hline $0.5-0.6$ & 102 & 2293 & 29.095 & 28.715 & 0.014 & -0.006 & -0.061 \\
\hline Total & 351 & & 100.00 & 100.00 & & -0.081 & \\
\hline
\end{tabular}

Flow accumulation or upslope contributing area: Flow accumulation or upslope contributing area refers to upslope area drained from a location in topographic position. The flow accumulation, which is calculated from the DEM, can be a proxy expression of a ridgeline, sites of residual soil, colluvium concentration, and moisture availability and drainage flow line (Beven and Kirkby 1979; Dietrich et al. 1995; Pack et al. 1999). Flow accumulation determines where the slope materials and rainwater are dispersed and where the flow of both water and slope materials tend to concentrate. The former is the divergent slopes and the later one is known as the 


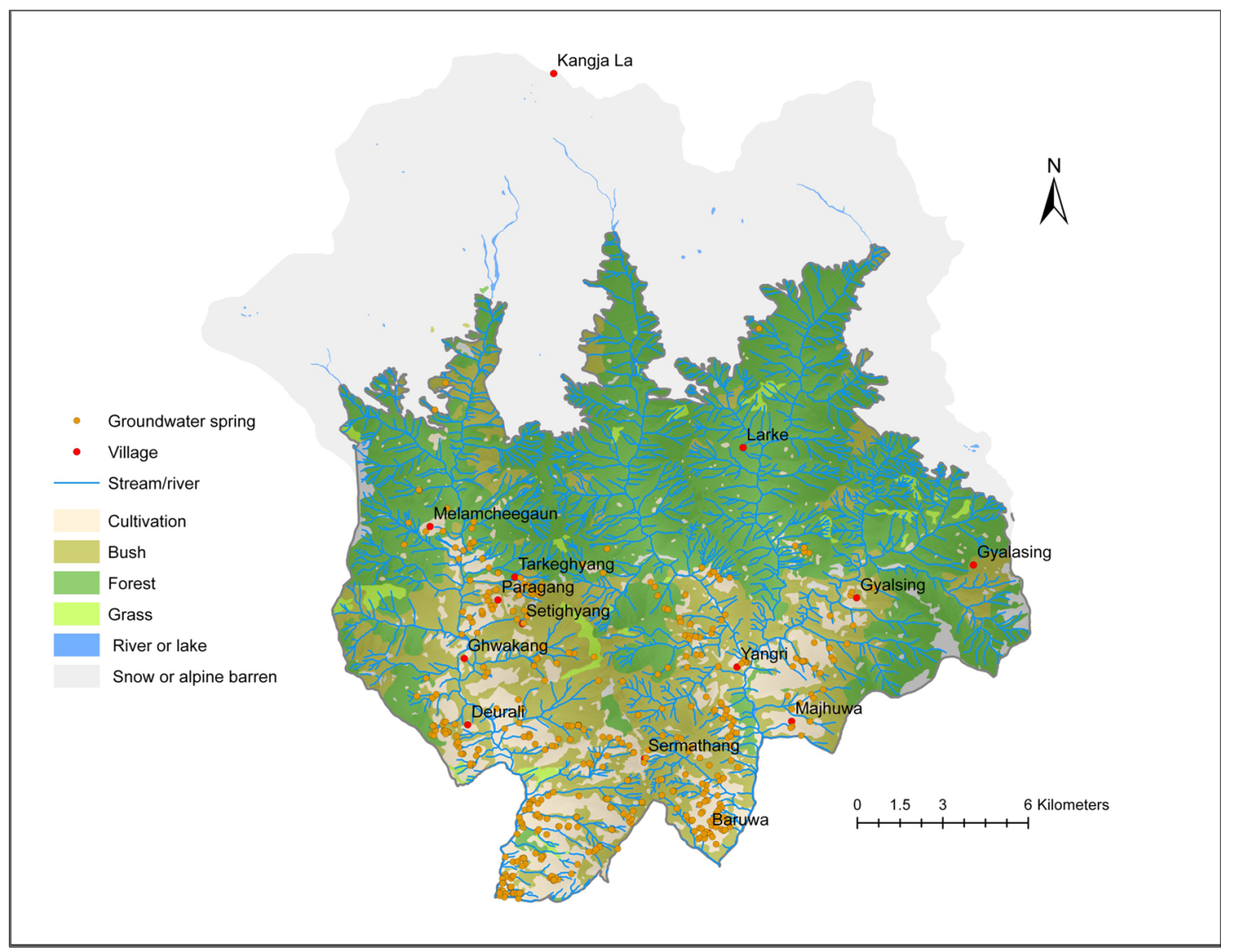

Figure 17. Land cover map of the study area.

convergent slope, which are potential areas for colluvium and saturation and recharge and seepage zone. The present study shows that the weight of occurrence of groundwater spring is high on locations, which receives the accumulation of water and sediment from the larger areas (figure 15). The flow accumulation zones and high discharge of springs in the study area are closely associated with the accumulation of hillslope deposits underlain by highly weathered or fractured rocks, which facilitate to transmit recharged water flow through the subsurface to surface (Winter 1998).

\subsubsection{Geology and lineaments}

Geology controls occurrence, movement and storage of groundwater. The petrography, stratigraphy, structure, lithology and thickness of a given rock type control the porosity and permeability, which define the storage capacity of an aquifer (Higgins et al. 1985; Winter 1998; Crawford and Kath 2005; Chinnasamy and Prathapar 2016). The shape, sorting and packing of grains in the rocks during their formation determine primary porosity. Secondary porosity, such as joints, fractures and solution opening, is formed after the rock has been deposited. The number and arrangement of fracture openings and the degree to which they are filled with fine-grained material control secondary porosity. The geological map (figure 2) shows the rock stratigraphy and lithology in different geological units as the wells major thrust, faults and lineaments, which contribute to varying hydraulic conductivity and permeability for occurrence, movement and storage of groundwater.

The weight of occurrence of ground spring water was found to be high in the Gyalthung, Shermathang, Dhadkhola Formation (table 4 and figure 16). Highly sheared and fractured rocks of gneiss, schist and quartzite beneath the soil and saprolite in these geological unit favour high infiltration rate and groundwater storage, which yield to discharge of ground spring water (Kerrich 1986; Florinsky 2000). Geological contacts, faults, joints, soil and other deposition characteristics (Higgins et al. 1985; Marklund and Wörman 2007; Younger 2007) intersecting the topographic features control the recharge and discharge of groundwater.

The presence of lineaments influences the potentiality of groundwater occurrence in the crystalline hard rock (Nag 2005; Kolawole et al. 2016). These lineaments in the study area generally 


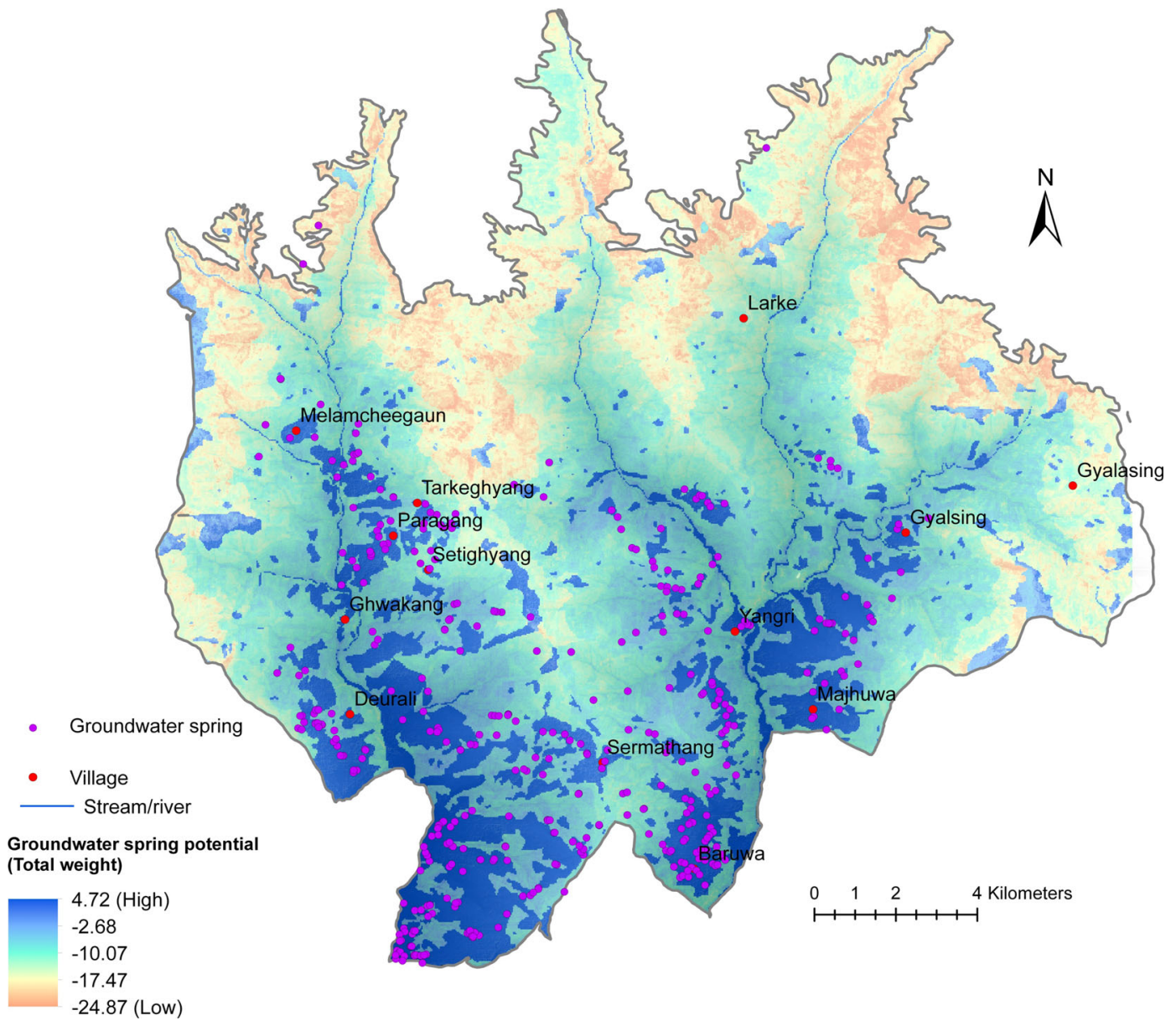

Figure 18. Groundwater spring potential zone.

represent the major joints and faults in the tectonically active areas, where the bedrocks are intensely deformed (Dhital et al. 2002; Dhital 2015). Hence, these lineaments act as a conduit for groundwater movement, which result in increased secondary porosity and therefore, can serve as the groundwater potential zone. In the study area, the lineaments were identified from Landsat-8 imagery and their line density was calculated, the weight of the groundwater spring occurrence strongly correlated with lineament density, i.e., $r^{2}=0.94$ $(P<0.01, n=5)$. This strongly supports the role of rock discontinuities in high-grade metamorphic rocks as groundwater aquifer and a conduit for both recharge and discharge of groundwater.

\subsubsection{Land use and vegetation density}

Land use is an important characteristic of the runoff process that affects the infiltration, erosion and evapotranspiration. Groundwater spring is well connected with the landscape and land use that it lies beneath. Land use affects the groundwater resources through changes in recharge and by changing demands for water (Lerner and Harris 2009; Prabhakar and Tiwari 2015). The weight of occurrence of ground spring water was found to be high in the forest areas and low in the barren areas (table 5 and figure 17). The normalised difference vegetation density index map also reveals the significant positive correlation (i.e., $\left.r^{2}=0.73 ; P<0.10, n=5\right)$ between the vegetation density and the groundwater spring occurrence. Dense vegetation in the study area lies in plane concave or flow accumulating slopes, where soils and colluvium deposits are deep and relatively moist to favour the vegetation growth as well as for high groundwater recharge to raise the groundwater level to the point where water issues as spring from the ground. It is recognised that forested land decreases the amount and velocity of storm runoff over the land surface. This, in turn, increases the amount of water that percolates into the ground, a portion of which can ultimately recharge underlying aquifers, which transmit groundwater flow to the surface as springs (Spears 1982; Myers 
All springs $(\mathrm{N}=401)$

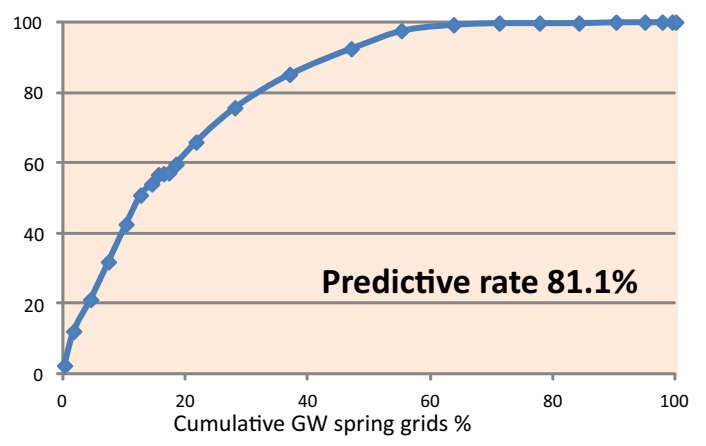

Not included springs $(\mathrm{N}=50)$

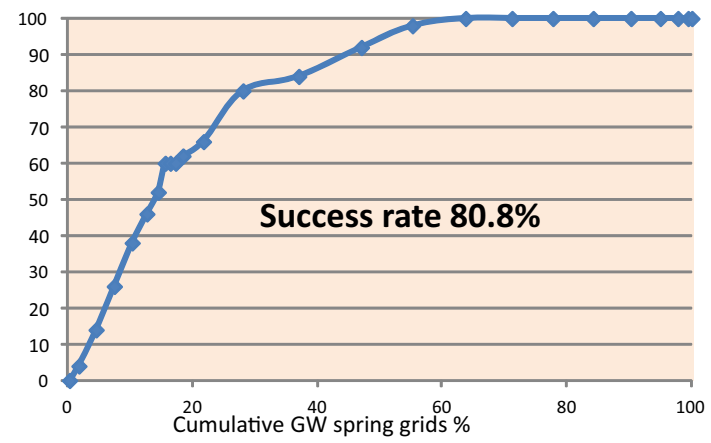

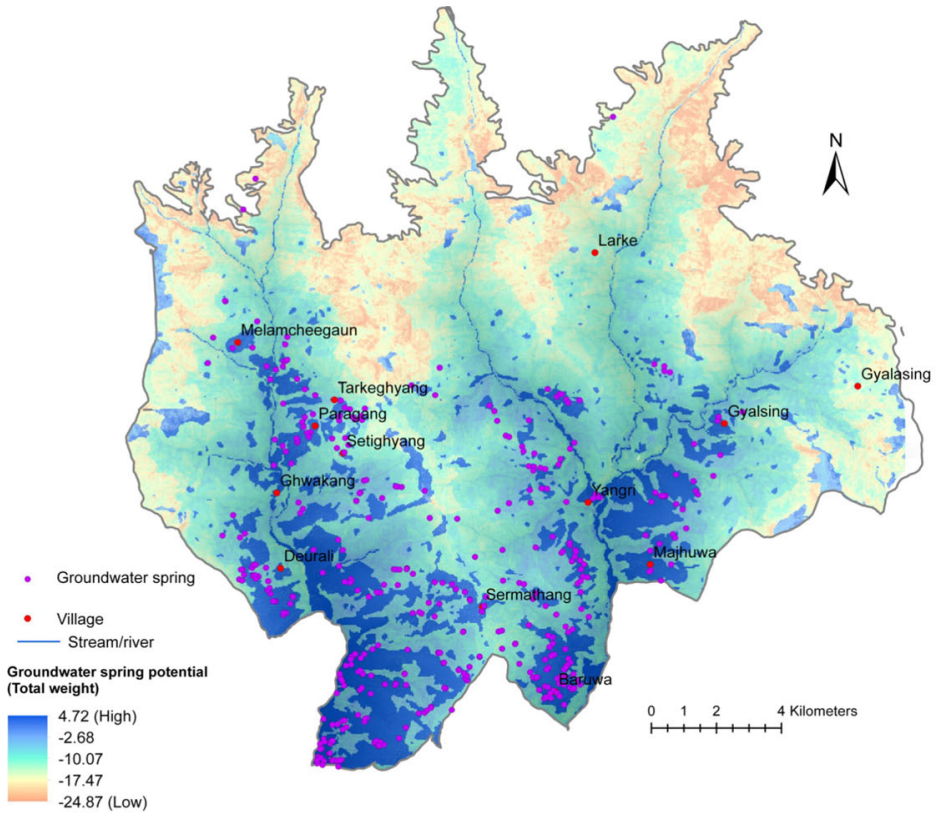

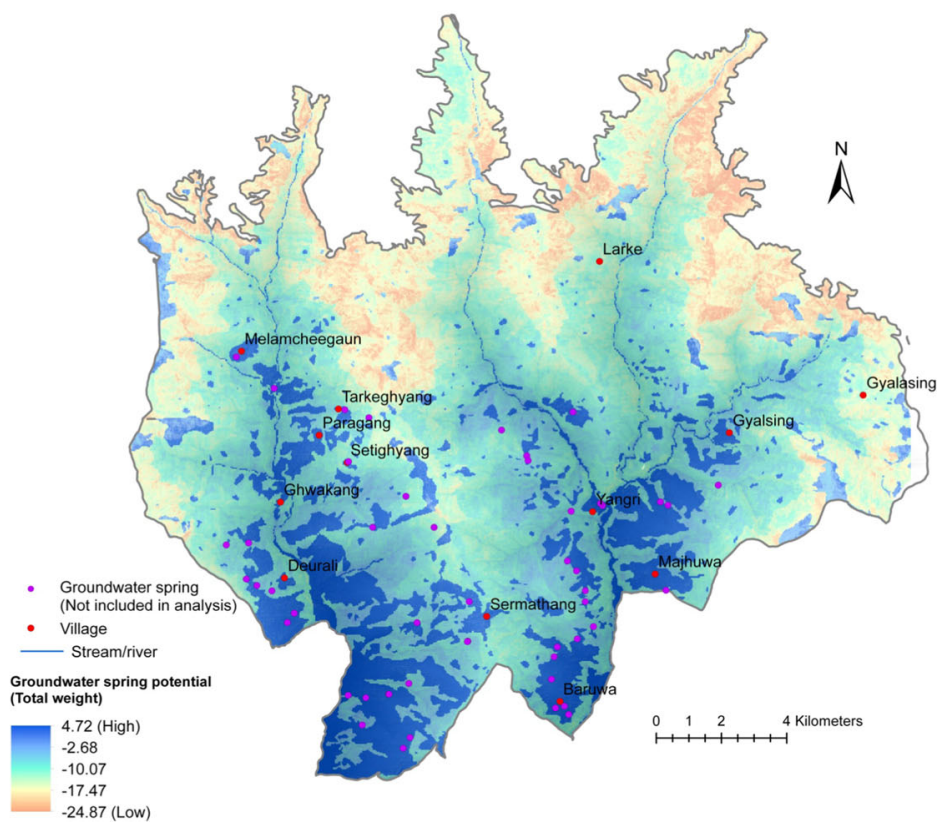

Figure 19. Predictive and success rate of groundwater spring potential zone.

1983; Bartarya 1989). Such spring flows, which feed streams and wetlands, help to maintain their water levels during dry periods. However, several studies suggest that forest may not be the best land cover to maximise water yield, regulate seasonal flows and ensure high water quality (summarised by Gilmour et al. 1987; Bruijnzeel 2004; Calder 2007; van Dijk et al. 2007; Ghimire et al. 2012). One evidence reveals that afforestation will increase interceptions typically, reduce local average water yield as well as low flows due to lower infiltration (Bruijnzeel 2004). The net effect of land cover on water yield will, however, depend on the characteristics of a given hydrogeologic landscape such as its bedrock geology and structure, surficial geology, soil type and topography (Smerdon et al. 2009).

\subsubsection{Groundwater spring potential map}

As stated earlier 11-factor maps were overlaid with the help of ArcGIS9.3 to get groundwater spring potential zone ( $\max$ value 4.81 ; min value -24.25 ; mean -1.14 ; standard deviation 2.87 ) as shown in 
the figure. The total weighted map was classified into four classes corresponding to very low potential, low potential, moderate potential and high potential (figure 18). The classification was based on the Jenks natural break on the histogram of index values on the continuous groundwater spring potential raster map.

\subsubsection{Prediction and success rate of groundwater spring potential zone and validation}

Validation was performed by comparison with all surveyed groundwater spring location data, using a prediction rate and success rate curves (figure 19). The prediction rate illustrates how well the estimation performs with respect to the spring locations used for constructing the groundwater spring potential zone map. Similarly, the success rate refers to how well the survey springs water locations that were not included for analyses conform to the estimated potential zones of groundwater spring. Fifty out of total surveyed springs were randomly not included in the analysis.

The predictive rate indicates that with a decrease in the index of groundwater spring potential, the occurrence of all surveyed groundwater spring progressively declines. Similarly, the success rate reveals that with a decrease in the index of groundwater potential, the occurrence of surveyed groundwater spring randomly not included, also progressively declines. In order to evaluate the prediction and the success rate of groundwater spring locations, area under the curve was estimated (figure 19). The area under the curve shows the prediction and success rate of $81.4 \%$ and $80 \%$ for the model, respectively, This indicates that the WoE model mapping for groundwater spring potential is valid and could be replicated elsewhere, where the data of groundwater from the hydrogeological survey is not available.

\section{Summary and conclusions}

The study has assessed the groundwater spring potential by applying GIS, which integrated and analysed the data obtained from the GPS survey, maps and satellite imageries in this part of the Himalaya. A spring GPS inventory map showing 412 groundwater spring locations was prepared from the field survey. These groundwater springs were mainly originated from the weathered-jointed or fractured rock aquifers in the high-grade metamorphosed rocks.

The analysis of association of these springs with in situ factors such as altitude, slope gradient, relative relief, slope shape, slope aspect, drainage density, flow accumulation, geology and lineaments, land use, and vegetation density was done through calculating weights, applying on WoE model. The weight indicated the likelihood of ground spring water occurrence in multiple classes of each factor.

Gentle slope class, low relative relief, high flow accumulation, north- and east-facing slopes, denser lineament density, altitude class of $1500-2500 \mathrm{~m}$, high vegetation density and forest demonstrated a higher likelihood of spring occurrence. The likelihood of occurrence was found to be very strong in arears of dense lineaments. Combining the weight maps of each of the chosen factors, potential groundwater spring map was produced, and validation of the map was successful.

The result indicates the WoE method of predicting groundwater potential could be replicated in a similar biophysical environment, where a hydrogeological or geophysical survey of groundwater has not been done. Nevertheless, the limitation of this statistical model is that it relies on the association of groundwater spring with casual in situ factors that are chosen without necessarily understanding the process and mechanism of the groundwater interaction with them. This limitation does not, however, undermine the importance of groundwater spring potential map in devising a strategy and programme for the conservation of spring seepage zones and a scientific evidence for planners, policy makers and managers in water resource management, land use planning and building climate resilience.

\section{Acknowledgements}

This paper was based on the research financed under the Climate Change Research Grants Program implemented by the Nepal Academy of Science and Technology. The programme is part of the Mainstreaming Climate Change Risk Management in the Development project. This project is a component of Nepal's Pilot Program for Climate Resilience and is executed by the Ministry of Population and Environment (Nepal), financed by the Climate Investment Funds, administered by the Asian Development Bank with technical assistance from ICEM, METCON and APTEC. The authors 
also express their sincere thanks to Mr. Sukadev Khanal and Mr. Udhab Karki who have assisted for GPS-based groundwater spring inventory in the field.

\section{References}

Abuzied S M and Alrefaee H A 2017 Mapping of groundwater prospective zones integrating remote sensing, geographic information systems and geophysical techniques in El-Qaà Plain area, Egypt; Hydrogeol. J. 25(7) 2067-2088.

Agrawala S, Raksakulthai V, van Aalst M, Larsen P, Smith J and Reynolds J 2003 Development and climate change in Nepal: Focus on water resources and hydropower; OECD, Paris.

Alley W M, Healy R W, LaBaugh J W and Reilly T E 2002 Flow and storage in groundwater systems; Science 296(5575) 1985-1990.

Andermann C, Longuevergne L, Bonnet S, Crave A, Davy $\mathrm{P}$ and Gloaguen R 2012 Impact of transient groundwater storage on the discharge of Himalayan rivers; Nat. Geosci. 5(2) $127-132$.

Bartarya S 1989 Hydrogeology, geo-environmental problems and watershed management strategies in a central Himalayan river basin, Kumaun, India; Headwater Control IUFRO/WASWC/CSVIS, Plzen, Czechoslovakia, pp. 308-318.

Bates B, Kundzewicz Z and Wu S 2008 Climate change and water; Intergovernmental Panel on Climate Change Secretariat.

Beven K J and Kirkby M J 1979 A physically based, variable contributing area model of basin hydrology/Un modèle à base physique de zone d'appel variable de l'hydrologie du bassin versant; Hydrolog. Sci. J. 24(1) 43-69.

Bonham-Carter G F 1994 Geographic information systems for geoscientists - modeling with GIS; Comp. Meth. Geos. 13398.

Bookhagen B and Burbank D W 2010 Toward a complete Himalayan hydrological budget: Spatiotemporal distribution of snowmelt and rainfall and their impact on river discharge; J. Geophys. Res. Earth 11(F3), https://doi. org/10.1029/2009JF001426.

Brekke L D 2009 Climate change and water resources management: A federal perspective; DIANE Publishing.

Bruijnzeel L A 2004 Hydrological functions of tropical forests: Not seeing the soil for the trees?; Agr. Ecosyst. Environ. 104(1) 185-228.

Calder I R 2007 Forests and water - ensuring forest benefits outweigh water costs; Forest Ecol. Manag. 251(1) 110120.

Chapagain P S, Ghimire M and Shrestha S 2017 Status of natural springs in the Melamchi region of the Nepal Himalayas in the context of climate change; Environ. Dev. Sustain., https://doi.org/10.1007/s10668-017-0036-4.

Chinnasamy P and Prathapar S A 2016 Methods to investigate the hydrology of the Himalayan springs: A review, Vol. 169, International Water Management Institute (IWMI)

Crawford T J and Kath R L 2005 Ground water exploration and development in igneous and metamorphic rocks of the southern Piedmont/Blue Ridge; Georgia Institute of Technology.

Dhital M R 2015 Geology of the Nepal Himalaya: Regional perspective of the classic collided Orogen; Springer.

Dhital M R, Sunuwar S C and Shrestha R 2002 Geology and structure of the Sundarijal-Melamchi area, central Nepal; In: Third Nepal Geological Congress, 21p.

Dietrich W E, Reiss R, Hsu M L and Montgomery D R 1995 A process-based model for colluvial soil depth and shallow landsliding using digital elevation data; Hydrol. Process. 9(3-4) 383-400.

DMG 2005 Geological map of parts of Sindhupalchok and Nuwakot District, Sheet No. 2785-03(72E/9), Department of Mines and Geology, Kathmandu.

Florinsky I V 2000 Relationships between topographically expressed zones of flow accumulation and sites of fault intersection: Analysis by means of digital terrain modeling; Environ. Modell. Softw. 15(1) 87-100.

Forster C and Smith L 1988 Groundwater flow systems in mountainous terrain: 2. Controlling factors; Water Resour. Res. 24(7) 1011-1023.

Galassi D M, Lombardo P, Fiasca B, Di Cioccio A, Di Lorenzo T, Petitta M and Di Carlo P 2014 Earthquakes trigger the loss of groundwater biodiversity; Sci. Rep.-UK 46273.

Ganapuram S, Kumar G V, Krishna I M, Kahya E and Demirel M C 2009 Mapping of groundwater potential zones in the Musi basin using remote sensing data and GIS; Adv. Eng. Softw. 40(7) 506-518.

Ghimire M 2011 Landslide occurrence and its relation with terrain factors in the Siwalik Hills, Nepal: Case study of susceptibility assessment in three basins; Nat. Hazards 56(1) 299-320.

Ghimire C P, Bruijnzeel L A, Lubczynski M W and Bonell M 2012 Rainfall interception by natural and planted forests in the Middle Mountains of Central Nepal; J. Hydrol. 475 270-280.

Gilmour D A, Bonell M and Cassells D 1987 The effects of forestation on soil hydraulic properties in the Middle Hills of Nepal: A preliminary assessment; Mt. Res. Dev. 239-249.

Green T R 2016 Linking climate change and groundwater; In: Integrated groundwater management, Springer, pp. 97141.

Greenbaum D 1992 Structural influences on the occurrence of groundwater in SE Zimbabwe; Geol. Soc. London Spec. Publ. 66(1) 77-85.

Gurdak J S, Hanson R T and Green T R 2009 Effects of climate variability and change on groundwater resources of the United States; US Geological Survey.

Guru B, Seshan K and Bera S 2016 Frequency ratio model for groundwater potential mapping and its sustainable management in cold desert, India; J. King Saud Univ.-Sci. 29(3) 333-347.

Gurung G B and Nepal P A 2007 Watershed management approach for climate change adaptation practical action; Kathmandu, Nepal.

Higgins M W, Atkins R L, Crawford T J, Crawford III R F, Brooks R and Cook R B 1985 Structure, stratigraphy, tectonostratigraphy, and evolution of the southernmost part of the Appalachian orogen, Georgia and Alabama; Geol. Soc. Am. Abstr. Programs USA, 17. 
Hudson R and Anderson A 2006 Russell creek: Summary of research and implications for professional practice $\mathrm{BC}$ ministry of forests and range, coast forest region, Nanaimo, BC extension note no. EN 22.

Hydrological Studies 2017 http://www.gwrdb.gov.np/ publications.php.

ICIMOD 2015 Reviving the drying springs reinforcing social development and economic growth in the Midhills of Nepal; Kathmandu.

Immerzeel W W, Van Beek L P and Bierkens M F 2010 Climate change will affect the Asian water towers; Science 328(5894) 1382-1385.

Jaiswal R, Mukherjee S, Krishnamurthy J and Saxena R 2003 Role of remote sensing and GIS techniques for generation of groundwater prospect zones towards rural development - An approach; Int. J. Remote Sens. 24(5) 993-1008

Jensen J R 2009 Remote sensing of the environment: An earth resource perspective; 2nd edn, Pearson Education India.

Jha M K, Chowdhury A, Chowdary V and Peiffer S 2007 Groundwater management and development by integrated remote sensing and geographic information systems: Prospects and constraints; Water Resour. Manag. 21(2) 427-467.

Karmacharya J, Shrestha A, Rajbhandari R and Shrestha M 2007 Climate change scenarios for Nepal based on regional climate model RegCM3, Final report; Department of Hydrology and Meteorology, Nepal.

Kerrich R 1986 Fluid transport in lineaments; Phil. Trans. Roy. Soc. London A 317 219-251.

Kolawole M, Ishaku J, Daniel A and Owonipa O 2016 Lineament mapping and groundwater occurrence within the vicinity of Osara Dam, Itakpe-Okene area, North Central Nigeria, using landsat data; J. Geosci. Geomatics 4 $42-52$.

Krishnamurthy J, Venkatesa Kumar N, Jayaraman V and Manivel M 1996 An approach to demarcate ground water potential zones through remote sensing and a geographical information system; Int. J. Remote Sens. 17(10) 18671884.

Lavé J and Avouac J 2001 Fluvial incision and tectonic uplift across the Himalayas of central Nepal; J. Geophys. Res.Sol. Ea 106(B11) 26561-26591.

Lerner D N and Harris B 2009 The relationship between land use and groundwater resources and quality; Land Use Policy 26 S265-S273.

Machiwal D and Singh P 2015 Comparing GIS-based multicriteria decision-making and Boolean logic modelling approaches for delineating groundwater recharge zones; Arab. J. Geosci. 8(12) 10675-10691.

Magesh N, Chandrasekar N and Soundranayagam J P 2012 Delineation of groundwater potential zones in Theni district, Tamil Nadu, using remote sensing, GIS and MIF techniques; Geosci. Front. 3(2) 189-196.

Mahamuni K and Kulkarni H 2012 Groundwater resources and spring hydrogeology in South Sikkim, with special reference to climate change; In: Climate Change Sikkim Patterns, Impacts, Initiatives, pp 261-274.

Marklund L and Wörman A 2007 The impact of hydraulic conductivity on topography driven groundwater flow; Publs. Inst. Geophys. Pol. Acad. Sci. E 7 159-167.
Moghaddam D D, Rezaei M, Pourghasemi H, Pourtaghie Z and Pradhan B 2015 Groundwater spring potential mapping using bivariate statistical model and GIS in the Taleghan watershed, Iran; Arab J. Geosci. 8(2) 913929.

Montgomery D R and Manga M 2003 Streamflow and water well responses to earthquakes; Science $\mathbf{3 0 0 ( 5 6 2 8 )} 2047$ 2049 .

Mukherjee S 1996 Targeting saline aquifer by remote sensing and geophysical methods in a part of Hamirpur-Kanpur, India; Hydrogeol. J. 19 53-64.

Mukherjee A, Saha D, Harvey C F, Taylor R G, Ahmed K M and Bhanja S N 2015 Groundwater systems of the Indian sub-continent; J. Hydrol. Reg. Stud. 4 1-14.

Murthy K 2000 Ground water potential in a semi-arid region of Andhra Pradesh - a geographical information system approach; Int. J. Remote Sens. 21(9) 18671884 .

Myers N 1983 Tropical moist forests: Over-exploited and under-utilized?; Forest Ecol. Manag. 6(1) 59-79.

Nag S 2005 Application of lineament density and hydrogeomorphology to delineate groundwater potential zones of Baghmundi block in Purulia district, West Bengal; J. Indian Soc. Remote Sens. 33(4) 521-529.

Nobre R, Rotunno Filho O, Mansur W, Nobre M and Cosenza C 2007 Groundwater vulnerability and risk mapping using GIS, modeling and a fuzzy logic tool; J. Contam. Hydrol. 94(3) 277-292.

NRSA 1987 Land and water resources survey of droughtaffected district - Kolar, Karnataka; Technical Report, Hyderabad.

Oh H-J, Kim Y-S, Choi J-K, Park E and Lee S 2011 GIS mapping of regional probabilistic groundwater potential in the area of Pohang City, Korea; J. Hydrol. 399(3) 158 172.

Ozdemir A 2011 GIS-based groundwater spring potential mapping in the Sultan Mountains (Konya, Turkey) using frequency ratio, weights of evidence and logistic regression methods and their comparison; J. Hydrol. 411(3) 290308.

Pack R T, Tarboton D and Goodwin C 1999 SINMAP 2.0 - A stability index approach to Terrain stability hazard mapping, user's manual.

Palazzoli I, Maskey S, Uhlenbrook S, Nana E and Bocchiola D 2015 Impact of prospective climate change on water resources and crop yields in the Indrawati basin Nepal; Agr. Syst. 133 143-157.

Pandey V P, Chapagain S K and Kazama F 2010 Evaluation of groundwater environment of Kathmandu Valley; Environ. Earth Sci. 60(6) 1329-1342.

Pandey V P, Shrestha S and Kazama F 2013 A GIS-based methodology to delineate potential areas for groundwater development: A case study from Kathmandu Valley, Nepal; Appl. Water Sci. 3(2) 453-465.

Pathak D R, Hiratsuka A, Awata I and Chen L 2009 Groundwater vulnerability assessment in shallow aquifer of Kathmandu Valley using GIS-based DRASTIC model; Environ. Geol. 57(7) 1569-1578.

Patil S G and Mohite N M 2014 Identification of groundwater recharge potential zones for a watershed using remote sensing and GIS; Int. J. Geomat. Geosci. 4(3) 485 . 
Paudel S and Vetaas O R 2014 Effects of topography and land use on woody plant species composition and beta diversity in an arid Trans-Himalayan landscape, Nepal; J. Mt. Sci.-Engl. 11(5) 1112-1122.

Peking University TU 2013 Climate change adaptation through water resource management: Comparative study between Yellow and Koshi River Basins; Peking University and Tribhuvan University, Kathmandu.

Prabhakar A and Tiwari H 2015 Land use and land cover effect on groundwater storage; Model Earth Syst. Environ. 1(4) 45.

Pradhan B 2009 Groundwater potential zonation for basaltic watersheds using satellite remote sensing data and GIS techniques; Cent. Eur. J. Geosci. 1(1) 120-129.

Pradhan N S, Sijapati S and Bajracharya S R 2015 Farmers' responses to climate change impact on water availability: Insights from the Indrawati Basin in Nepal; Int. J. Water Resour. D31(2) 269-283.

Rao N S 2006 Groundwater potential index in a crystalline terrain using remote sensing data; Environ. Geol. 50(7) 1067-1076.

Sabins F F 2007 Remote sensing: Principles and applications; Waveland Press.

Salama R, Tapley I, Ishii T and Hawkes G 1994 Identification of areas of recharge and discharge using Landsat-TM satellite imagery and aerial photography mapping techniques; J. Hydrol. 162(1-2) 119-141.

Saraf A and Choudhury P 1998 Integrated remote sensing and GIS for groundwater exploration and identification of artificial recharge sites; Int. J. Remote Sens. 19(10) 1825-1841.

Sener E, Davraz A and Ozcelik M 2005 An integration of GIS and remote sensing in groundwater investigations: A case study in Burdur, Turkey; Hydrogeol. J. 13 826-834.

Shaban A, Khawlie M and Abdallah C 2006 Use of remote sensing and GIS to determine recharge potential zones: The case of Occidental Lebanon; Hydrogeol. J. 14 433443.

Shahid S, Nath S and Roy J 2000 Groundwater potential modelling in a soft rock area using a GIS; Int. J. Remote Sens. 21(9) 1919-1924.

Sharma B et al. 2016 Springs, storage towers, and water conservation in the midhills of Nepal; ICIMOD Working Paper.
Smerdon B D, Redding T and Beckers J 2009 An overview of the effects of forest management on groundwater hydrology; J. Ecosyst. Manag. 10(1) 22-44.

Solomon S and Quiel F 2006 Groundwater study using remote sensing and geographic information systems (GIS) in the central highlands of Eritrea; Hydrogeol. J. 141029 1041.

Spears J 1982 Rehabilitating watersheds; Financ. Dev. 19(1) 30-33.

Spiegelhalter D J 1986 A statistical view of uncertainty artificial intelligence $\&$ statistics (ed.) Gale WA, Addison Wesley.

Tambe S, Kharel G, Arrawatia M, Kulkarni H, Mahamuni K and Ganeriwala A K 2012 Reviving dying springs: Climate change adaptation experiments from the Sikkim Himalaya; Mt. Res. Dev. 32(1) 62-72.

Thangarajan M 2007 Groundwater flow and mass transport modeling; Capital Pub. Co.

Tweed S O, Leblanc M, Webb J A and Lubczynski M W 2007 Remote sensing and GIS for mapping groundwater recharge and discharge areas in salinity prone catchments, southeastern Australia; Hydrogeol. J. 15 7596.

Valdiya K and Bartarya S 1989 Diminishing discharges of mountain springs in a part of Kumaun Himalaya; Curr. Sci. 58(4) 417-426.

van Dijk A I, Hairsine P B, Arancibia J P and Dowling T I 2007 Reforestation, water availability and stream salinity: A multi-scale analysis in the Murray-Darling Basin, Australia; Forest Ecol. Manag. 251(1) 94-109.

Van Westen C 2002 Use of weights of evidence modeling for landslide susceptibility mapping; International Institute for Geoinformation Science and Earth Observation, Enschede, The Netherlands.

WECS/IMWI 2002 Integrated development and management of water resources in the Indrāvati Basin, Nepal; Project Synthesis Report, Kathmandu.

Winter T C 1998 Ground water and surface water: A single resource, Vol. 1139, DIANE Publishing Inc.

Yeh H-F, Lee C-H, Hsu K-C and Chang P-H 2009 GIS for the assessment of the groundwater recharge potential zone; Environ. Geol. 58(1) 185-195.

Younger P L 2007 Groundwater in the environment: An introduction; John Wiley \& Sons. 